\title{
Bioinoculant production composed by Pseudomonas sp., Serratia sp., and Kosakonia sp., preliminary effect on Allium cepa L., growth at plot scale
}

\author{
Andrea Blanco-Vargas ${ }^{1,2,3}$, Lina M. Rodríguez-Gacha ${ }^{1}$, Natalia Sánchez-Castro ${ }^{1}$, Laura \\ Herrera-Carlosama ${ }^{1}$, Raúl A. Poutou-Piñales ${ }^{2}$, Lucía A. Díaz-Ariza ${ }^{3}$, Viviana \\ Gutiérrez-Romero $^{4}$, Claudia M. Rivera-Hoyos ${ }^{1,2}$, Leidy D. Ardila-Leal ${ }^{1,2}$, Aura M. \\ Pedroza-Rodríguez*1
}

\section{Edited by}

Juan Carlos Salcedo-Reyes

salcedo.juan@javeriana.edu.co

1. Pontificia Universidad Javeriana, Facultad de Ciencias, Departamento de Microbiología, Unidad de Investigaciones Agropecuarias (UNIDIA), Carrera 7 No 43-82, Bogotá, D.C., Colombia, Código postal 110-23

\section{Pontificia Universidad Javeriana,} Facultad de Ciencias, Departamento de Microbiología, Grupo de Biotecnología Ambiental e Industrial (GBAI), Carrera 7 No 43-82, Bogotá, D.C., Colombia, Código postal 110-23

3. Pontificia Universidad Javeriana, Facultad de Ciencias, Departamento de Biología, Grupo de Investigación en Agricultura Biológica. Carrera 7 No 43-82, Bogotá, D.C., Colombia, Código postal $110-23$

4. Konservo S.A.S. Desarrollos Agroindustriales Sostenibles, carrera 59a No 68-36, Bogotá, D.C., Colombia

*apedroza@javeriana.edu.co

Received: $30-4-2020$

Accepted: 18-1-2021

Published online: 25-5-2021

Citation: Blanco-Vargas A, Rodríguez-Gacha LM, Sánchez-Castro N, Herrera-Carlosama L, Poutou-Piñales RA, Díaz-Ariza LA, Gutiérrez-Romero EV, Rivera-Hoyos CM, Ardila-Leal DM, Pedroza-Rodríguez AM. Bioinoculant production composed by Pseudomonas sp., Serratia sp., and Kosakonia sp., preliminary effect on Allium cepa $\mathrm{L}$., growth at plot scale, Universitas

Scientiarum, 26(1): 79-118, 2021. doi: $10.11144 / J a v e r i a n a . S C 26-1 . e o b p$

\begin{abstract}
Phosphorus (P) is an essential nutrient for plant's development, and its deficiency restricts crop yield. To meet $P$ requirements in agricultural settings, a low-cost culture medium (MT11B) was designed in which a bioinoculant was produced consisting of three bacterial isolates capable of solubilizing P from phosphoric rock (PR). Pseudomonas sp., Serratia sp., and Kosakonia sp. exhibited $P$ solubilization in SMRS1 agar modified with PR $\left(5.0 \mathrm{~g} \mathrm{~L}^{-1}\right)$, as source of inorganic P. Sowings by isolation were made of the three bacteria on DNAse- and Blood-agar to rule out pathogenicity. At the interaction tests, no inhibition halos were observed; demonstrating there was no antagonism among them, thus they were used to constitute a consortium. Growth curve (12 h) in MT11B demonstrated consortium grew in presence of PR, brewer's yeast hydrolysate, and glucose at concentrations $\left(2.5 \mathrm{~g} \mathrm{~L}^{-1}\right)$ fourfold lower than those in SMRS1 $\left(10.0 \mathrm{~g} \mathrm{~L}^{-1}\right)$; obtaining phosphate solubilizing bacteria of $(10.60 \pm 0.08) \log _{10} \mathrm{CFU} \mathrm{mL} \mathrm{m}^{-1}$ and, at $6 \mathrm{~h}$ of culture, acid and alkaline phosphatase enzyme volumetric activities of $(2.3 \pm 0.8)$ UP and $(3.80 \pm 0.13) \mathrm{UP}$, respectively. The consortium, releasing phosphorus at a rate of $(45.80 \pm 5.17) \mathrm{mg} \mathrm{L}^{-1}$ at $6 \mathrm{~h}$ of production, was evaluated as bioinoculant in onion plots for five months. Plants receiving a treatment that included $500 \mathrm{~mL}$ $\left(10 \times 10^{7} \mathrm{CFU} \mathrm{mL}{ }^{-1}\right)$ of bioinoculant plus $100 \mathrm{~kg} \mathrm{ha}^{-1}$ of an organic mineral fertilizer exhibited the highest determined response variables $((170.1 \pm 22.2) \mathrm{mm}$ bulb height, $(49.4 \pm 6.5) \mathrm{mm}$ bulb diameter, $(9.0 \pm 1.8) \mathrm{g}$ bulb dry weight, and $15.21 \mathrm{mg} \mathrm{bulb}^{-1}$ total phosphorus $)(p<0.05)$.
\end{abstract}

Keywords: Bioinoculant; phosphate rock; Pseudomonas sp; Serratia sp.; Kosakonia sp.; organic acids; phosphatases; Allium cepa L.

\section{Introduction}

Phosphorus $(\mathrm{P})$ is one of the essential inorganic plant nutrients, being required in processes that sustain plant growth, such as photosynthesis, respiration, and energy storage and transfer (Mukhtar et al. (2017); Lobo et al. (2019)). Moreover, P also constitutes molecules, such as proteins, phospholipids, coenzymes, and nucleic acids (De Oliveira Mendes et al. (2014)). In agricultural setups, soil P deficiency restricts crop yield (Beheshti et al. (2017)). Chemical fertilizers are a way to provide $\mathrm{P}$ to crops. However, its availability remains low due to bond formation with $\mathrm{Fe}^{3+}$ and $\mathrm{Al}^{3+}$ in acid soils and with $\mathrm{Ca}^{2+}$ and $\mathrm{Mg}^{+2}$ in alkaline soils (Solankia et al. (2018); Wei et al. 
Funding: The Government of Boyacá, and the Departamento Administrativo de Ciencia y Tecnología e Innovación y COLCIENCIAS, Grant No. 733 of 215 , Pontificia Universidad Javeriana Bogotá, D.C. Colombia Grant ID 8626 and Grant ID 7681

Electronic supplementary material: Supp. 1 and 2

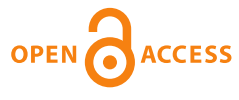

(2018)). Most phosphate chemical fertilizers are obtained from phosphate rock. Phosphate rock applications with other biotechnological strategies improve P solubilization and its availability in soils (Krishnaraj and Dahale (2014); Vassilev et al. (2014); Yadav et al. (2017)).

Since phosphate fertilizers continue on high demand and phosphate rock is a scarce non-renewable resource, it is necessary to use economically viable biotechnological strategies to reduce phospahte rock use by combining it with microorganisms. This makes suficcient $\mathrm{P}$ available to meet plant growth neeeds (Blanco-Vargas et al. (2020)).

Phosphate solubilizing bacteria (PSB) have been employed to improve soil P availability. PSB solubilize inorganic phosphate through different mechanisms via organic acid production and mineralize organic phosphate through the production of phosphatases (Beheshti et al. (2017); Munda et al. (2018); Tahir et al. (2018); Zhu et al. (2018)). Solubilization and mineralization processes mobilize the applied $\mathrm{P}$ and accumulate it in the soil, reducing fertilizer application costs (Behera et al. (2017)), improving the soil's quality, and re-establishing ecological equilibrium (Solankia et al. (2018)).

Bacteria belonging to the genera Pseudomonas, Serratia, and Enterobacter have the potential to increase phosphorus solubility, through the production of organic acids, such as acetic-, malic-, lactic-, succinic-, oxalic-, gluconic-, and citric-acid (Acevedo et al. (2014); Behera et al. (2014, 2017); Zhu et al. (2018); Rasul et al. (2019)). Additionally, the production of phosphatases increases P from organic sources (Ahemad and Kibret (2014); Beheshti et al. (2017); Lobo et al. (2019); Swetha and Padmavathi (2016)). The development of biological products based on these PSB is an alternative to the use of chemical synthetic products, as it diminishes the quantity of chemical fertilizer used, solubilizing the phosphate present in the soil (Lobo et al. (2019); Bushra et al. (2017)).

Onion (Allium cepa L.) is a crop of great importance in many countries (Petropoulos et al. (2015)). However, its cultivation is costly, particularly if obsolete soil management techniques continue being practiced (e.g. misuse of fertilizers that decrease in soil quality) (Ruiz et al. (2012)). Studies have been carried out on the fertility of soils where onion is grown, the interaction of its microorganisms, and fertilizer source. The recommended dose of phosphate requirements in onion culture is $80 \mathrm{~kg} \mathrm{ha}^{-1}$ (Boyhan et al. (2007)). Nutrient requirements are usually met with chemical fertilizers and PR (1.250 kg ha ${ }^{-1}$ ) (Álvarez-Hernández et al. (2011); Blanco and Lagos (2017)). However, the environmental impact of this practice and the imminent depletion of global phosphate rock reserves, has pressed the search for sustainable alternatives to meet $\mathrm{P}$ requirements in modern agriculture (Vaccari (2009); Patiño Torres and Sánchez De Prager (2012)).

Even though PSB are beneficial in agriculture, they are not sufficiently abundant in soils to compete with other microorganisms. Therefore, bio-inoculants composed of PSB are a valid strategy to increase productivity in agricultural ecosystems (Acevedo et al. (2014)). In this work we addressed the question whether bacteria inoculated in the soil of onion crops promote the solubilization of $\mathrm{P}$ from phosphoric rock and, therefore, onion growth. To do so we developed a bioinoculant from a consortium of PSB, isolated from soils where onion is grown in Boyacá, Colombia, and evaluated its effect on onion growth in the same crop system. 


\section{Materials and Methods}

\subsection{Soil sampling and isolation of PSB}

Soil sampling was conducted by employing a GPS eTREX Vista HCX ${ }^{\circledR}$ datum WGS 84 in two conventionally managed farms in the Suamox Valley (Boyacá, Colombia) where white onion is grown. The first site, named Punta Larga $\left(5^{\circ} 47^{\prime} 3.5^{\prime \prime} \mathrm{N}\right.$ and $\left.72^{\circ} 58^{\prime} 52.6^{\prime \prime} \mathrm{W}\right)$, had an area of $230 \mathrm{~m}^{2}$. In this area, 18 soil cores were collected at a depth of $20 \mathrm{~cm}$ of the plowed soil. The second site, known as Pesca $\left(5^{\circ} 36^{\prime} 58.5^{\prime \prime} \mathrm{N}\right.$ and $\left.73^{\circ} 1^{\prime} 42.0^{\prime \prime} \mathrm{W}\right)$ had an area of $400 \mathrm{~m}^{2}$, where 19 soil cores were sampled at a depth of $20 \mathrm{~cm}$ of the plowed soil. All of the soil samples were intended for chemical analyses $(\mathrm{pH})$ and counts of heterotrophic and phosphate solubilizing bacteria (Figure 1). All samples were dried for $24 \mathrm{~h}$ at room temperature to remove the humidity and sieved through a mesh $22 \mathrm{~mm}$ particle size. A geostatistical analysis, involving spatial autocorrelation with Moran's test and a spherical variogram model, was conducted to provide information about the sites' structure and parameters for kriging map interpolation.

Bacteria were isolated via serial soil dilutions $\left(1 \times 10^{-1}\right.$ to $\left.1 \times 10^{-7}\right)$. A total of $0.1 \mathrm{~mL}$ of each dilution was plated on SMRS1 agar containing $5.0 \mathrm{~g} \mathrm{~L}^{-1} \mathrm{Ca}_{3}\left(\mathrm{PO}_{4}\right)_{2}, 10 \mathrm{~g} \mathrm{~L}^{-1}$ glucose, $0.5 \mathrm{~g} \mathrm{~L}^{-1}$ yeast extract, $0.5 \mathrm{~g} \mathrm{~L}^{-1}\left(\mathrm{NH}_{4}\right)_{2} \mathrm{SO}_{4}, 0.2 \mathrm{gL}^{-1} \mathrm{KCl}, 0.3 \mathrm{gL}^{-1} \mathrm{MgSO}_{4}, 0.004 \mathrm{~g} \mathrm{~L}^{-1}$ $\mathrm{MnSO}_{4}, 0.0004 \mathrm{~g} \mathrm{~L}^{-1} \mathrm{FeSO}_{4}, 0.2 \mathrm{~g} \mathrm{~L}^{-1} \mathrm{NaCl}$, and $20 \mathrm{~g} \mathrm{~L}^{-1}$ agar, at $\mathrm{pH} 7.2 \pm 0.2$ (Paul and Sundara (1971)). Petri dishes were incubated for $72 \mathrm{~h}$ at $30^{\circ} \mathrm{C}$ and total bacteria (TB) and PSB were quantified. PSB colonies were distinguished from the others by the presence of a solubilization halo and a change in media color from purple to yellow, due to media acidification. Colonies presenting a solubilization halo were picked for sub-culture in modified SMRS1 agar with PR as P source (Calboy ${ }^{\circledR}$; www.calboy.co, 2018), $\left(25 \% \mathrm{P}_{2} \mathrm{O}_{5}, 32 \% \mathrm{CaO}, 14 \% \mathrm{SiO}_{2}\right.$, $0.5 \%$ (w/v) $\mathrm{Al}_{2} \mathrm{O}_{3}, 5 \mathrm{~g} \mathrm{~L}^{-1} \mathrm{PR}$ ), (SMRS1-PR) (Blanco-Vargas et al. (2020)). Petri dishes were incubated for $72 \mathrm{~h}$ at $30^{\circ} \mathrm{C}$.
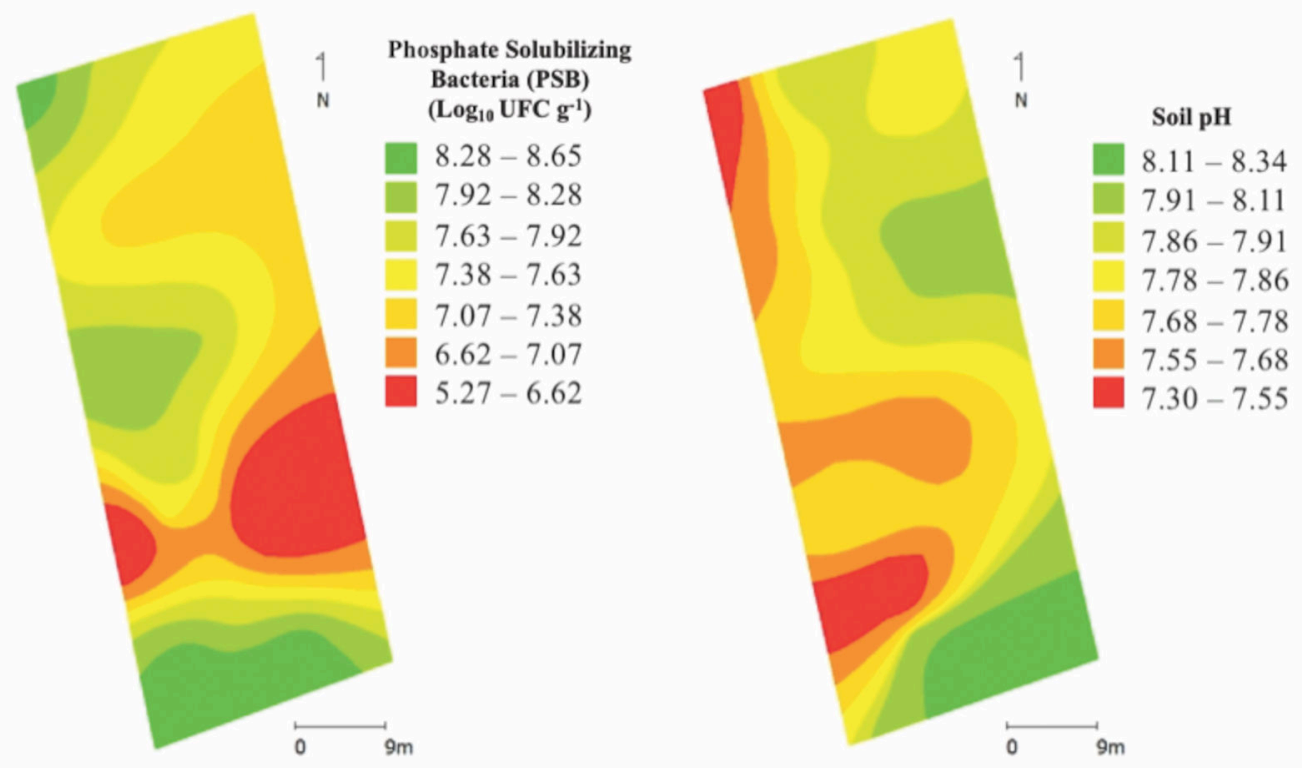

Figure 1: Spatial distribution of soil properties on Punta Larga site. Left, Phosphate Solubilizing Bacteria and Right, Soil pH. 
Gram negative rods were selected if they had a phosphate solubilization index SI $>2.0$. This SI was determined in SMRS1-PR agar using the microdrop technique Collins and Lyne (2004) following the protocol by Blanco-Vargas et al. (2020).

Antagonistic bacteria were assessed via agar diffusion in nutrient (NA) using the modified Gauze method (Blanco-Vargas et al. (2020); Hernández-Sáenz et al. (2020)). Non-antagonizing bacteria were employed for preliminary solubilization assays in liquid media containing PR. Additionally, to verify the non-pathogenic nature of the bacteria included in the consortium, each one was seeded (by isolation) on blood agar to verify the absence of $\beta$-hemolysis and on DNAse agar to rule out the presence of nucleases (Ahmad et al. (2013)).

\subsection{Solubilization preliminary assays}

Experiments were carried out in $100 \mathrm{~mL}$ Erlenmeyer shake-flasks with an effective work volume (EWV) of $25 \mathrm{~mL}$ in SMRS1-PR broth. The flasks were inoculated with $5 \%(\mathrm{v} / \mathrm{v})$ inoculum of each PSB adjusted the concentration to McFarland tube No. $1\left(3 \times 10^{8} \mathrm{CFU} \mathrm{mL}^{-1}\right)$. PSB cultures were performed under agitation at $120 \mathrm{rpm}$, at $30^{\circ} \mathrm{C}$, for $72 \mathrm{~h}$. As an absolute control, the same medium was used without inoculant. The response variables $\mathrm{pH}$ and colony forming units were evaluated in each culture. Colony forming unit was expressed as $\log _{10} \mathrm{CFU} \mathrm{mL}-1$ by the serial dilution method and SMRS1-PR agar surface seeding (Angulo-Cortés et al. (2012)). The concentration of soluble phosphate $\left(\mathrm{mg} \mathrm{L}^{-1}\right)$ was measured in the supernatant of each PSB culture after centrifugation for $20 \mathrm{~min}$ at $3578 \times g$ (Murphy and Riley (1958)). The Spectroquant ${ }^{\circledR}$ phosphate assay was used (MQuantTM Phosphate Test, Merck, Colombia) at OD $\lambda_{357 \mathrm{~nm}}$ and calculated based on the concentration of a standard curve $\left(0.5 \mathrm{mg} \mathrm{L}^{-1}\right.$ to $6.0 \mathrm{mg} \mathrm{L}^{-1}$ orthophosphates, $y=0.1477 x-0.0697, R^{2}=0.9980$. Additionally, residual glucose $\left(\mathrm{g} \mathrm{L}^{-1}\right)$ was determined using the DNS technique (Miller (1959)) with readings at OD at $\lambda 540 \mathrm{~nm}$ and detection limits between $0.2 \mathrm{~g} \mathrm{~L}^{-1}$ and $2.0 \mathrm{~g} \mathrm{~L}^{-1}$. All measurements were performed in triplicate. Based on these results, isolates that presented counts $>1.0 \times 10^{7} \mathrm{CFU} \mathrm{mL}^{-1}$ and soluble P SP $>48 \mathrm{mg} \mathrm{L}^{-1}$ were selected (Suppl. 1). Isolates for which cultures revealed significant counts and soluble $\mathrm{P}$ (according to ANOVA analysis and Tukey post hoc tests) were molecularly identified and selected to constitute the bacterial consortium (Parastesh et al. (2019)). For all assays a significance threshold of $5 \%(\alpha=0.05)$ was established. Analyses were performed using Statistics V 9.0 ${ }^{\circledR}$ software.

\subsection{MT11B culture media design}

To establish the culture media components and operating conditions best suited for PSB consortia growth (expressed as $\log _{10} \mathrm{CFU} \mathrm{mL} \mathrm{mL}^{-1}$ ), a Plackett-Burman experiment was conducted with six factors at two levels $(+1 ;-1)$ and one central point $(\mathrm{CP})$, evaluated in triplicate. The considered factors and levels are presented in Table 1. Additionally, response variables, such as soluble $\mathrm{P}$ concentration $\left(\mathrm{mg} \mathrm{L}^{-1}\right), \mathrm{pH}$, and residual glucose concentration were measured.

Assays with each test medium were performed in $100 \mathrm{~mL}$ Erlenmeyer shake-flasks with an effective work volume (EWV) of $25 \mathrm{~mL}$ at $30^{\circ} \mathrm{C}$ according to the experimental design combinations shown in Table 1. After completing the evaluation times (factor F), PSB count and soluble P concentrations were assessed as in the preliminary solubilization assays. The twelve treatments and the $\mathrm{CP}$ (evaluated in triplicate) had the base salt formulation of the SMRS1 medium $\left(0.5 \mathrm{~g} \mathrm{~L}^{-1}\left(\mathrm{NH}_{4}\right)_{2} \mathrm{SO}_{4}\right.$, $0.2 \mathrm{~g} \mathrm{~L}^{-1} \mathrm{KCl}, 0.3 \mathrm{~g} \mathrm{~L}^{-1} \mathrm{MgSO}_{4}, 0.004 \mathrm{gL}^{-1} \mathrm{MnSO}_{4}, 0.0004 \mathrm{gL}^{-1} \mathrm{FeSO}_{4}, 0.2 \mathrm{~g} \mathrm{~L}^{-1} \mathrm{NaCl}$ ). ANOVA and regression analysis were performed and using Design Expert V9.0. 
Table 1: Plackett-Burman Experimental Design, to determine the best culture media and operating conditions for Phosphate Solubilizing Bacteria (PSB).

\begin{tabular}{|c|c|c|c|c|c|c|}
\hline \multicolumn{7}{|c|}{ EVALUATED FACTORS } \\
\hline \multirow{2}{*}{ TREATMENT } & $\mathbf{A}$ & B & C & D & $\mathbf{E}$ & $\mathbf{F}$ \\
\hline & $\begin{array}{c}\mathrm{PR} \\
\left(\mathrm{g} \mathrm{L}^{-1}\right)\end{array}$ & $\begin{array}{l}\text { Glucose } \\
\left(\mathrm{g} \mathrm{L}^{-1}\right)\end{array}$ & $\begin{array}{l}\text { Brewers yeast hydrolysate } \\
\qquad\left(\mathrm{g} \mathrm{L}^{-1}\right)\end{array}$ & Agitation (rpm) & $\begin{array}{l}\text { Inoculum \% (v/v) PSB } \\
\left(4.7 \times 10^{8} \mathrm{CFU} \mathrm{mL}^{-1}\right)\end{array}$ & Culture Time (h) \\
\hline 1 & 5 & 5 & 0.25 & 200 & 10 & 48 \\
\hline 2 & 2.5 & 5 & 0.5 & 120 & 10 & 48 \\
\hline 3 & 5 & 2.5 & 0.5 & 200 & 5 & 48 \\
\hline 4 & 2.5 & 5 & 0.25 & 200 & 10 & 12 \\
\hline 5 & 2.5 & 2.5 & 0.5 & 120 & 10 & 48 \\
\hline 6 & 2.5 & 2.5 & 0.25 & 200 & 5 & 48 \\
\hline 7 & 5 & 2.5 & 0.25 & 120 & 10 & 12 \\
\hline 8 & 5 & 5 & 0.25 & 120 & 5 & 48 \\
\hline 9 & 5 & 5 & 0.5 & 120 & 5 & 12 \\
\hline 10 & 2.5 & 5 & 0.5 & 200 & 5 & 12 \\
\hline 11 & 5 & 2.5 & 0.5 & 200 & 10 & 12 \\
\hline 12 & 2.5 & 2.5 & 0.25 & 120 & 5 & 12 \\
\hline $\mathbf{C P}$ & 3.75 & 3.75 & 0.375 & 160 & 7 & 30 \\
\hline CP & 3.75 & 3.75 & 0.375 & 160 & 7 & 30 \\
\hline $\mathbf{C P}$ & 3.75 & 3.75 & 0.375 & 160 & 7 & 30 \\
\hline
\end{tabular}

\subsection{Growth curve and biomass production in MT11B culture media}

A Placket Burman experimental design growth curve in the chosen medium (MT11B) was performed in triplicate for $12 \mathrm{~h}$, at $200 \mathrm{rpm}$, and temperature of $30^{\circ} \mathrm{C}$. Cultures took place in $100 \mathrm{~mL}$ Erlenmeyer shake-flasks containing a total medium volume of $25 \mathrm{~mL}$, EWV, and $10 \%(\mathrm{v} / \mathrm{v})$ PSB inoculum $\left(4.7 \times 10^{8} \mathrm{CFU} \mathrm{mL} \mathrm{mL}^{-1}\right)$. Samples were taken every $2 \mathrm{~h}$ by triplicate from the Erlenmeyer shake-flasks. The response variables assessed were colony forming units $\left(\log _{10} \mathrm{CFU} \mathrm{mL} \mathrm{mL}^{-1}\right)$ in SMRS1-PR agar (Blanco-Vargas et al. (2020)), residual glucose $\left(\mathrm{g} \mathrm{L}^{-1}\right)$ by DNS (Miller (1959)), $\mathrm{pH}$, and soluble P concentration ( $\mathrm{mg} \mathrm{L}^{-1}$ ) (Murphy and Riley (1962)). All determinations were performed in triplicate.

From the growth curve, the following productivity and yield parameters were calculated: growth volumetric velocity $\left(K_{0}, \mathrm{CFU} \mathrm{mL} \mathrm{mL}^{-1} \mathrm{~h}^{-1}\right)$, duplication time $\left(D_{t}, \mathrm{~h}\right)$ (Doran (2013)), biomass yield/substrate $Y_{(X / S)}$, (Equation 1), phosphorous/glucose yield $Y_{(P / S)}$ (Equation 2), biomass phosphorus/glucose productivity $P_{(X)}$ (Equation 3), soluble P Productivity $P_{(P / S)}$ enzyme, namely acid phosphatase and alkaline phosphatase productivity $P_{(\text {Enz) }}$ (Equation 4 ). A mean comparison was performed for all productivity and yield assessments between sampling times ( $6 \mathrm{~h}$ and $12 \mathrm{~h})$ to identify significant differences among them $(\alpha=0.05)$.

Employed equations for productivity and yield parameters, following Doran (2013):

\subsection{Biomass yield/substrate}

$$
Y_{(X / S)}=\frac{\mathrm{CFU}_{f}-\mathrm{CFU}_{i}}{S_{0}-S_{f}}
$$

Where: $Y_{(X / S)}$ is the biomass yield divided by the substrate (glucose) $\left(\mathrm{CFU} \mathrm{mL} \mathrm{m}^{-1} \mathrm{mg}^{-1}\right), \mathrm{CFU}_{f}$ final colony forming units $\left(\mathrm{CFU} \mathrm{mL} \mathrm{m}^{-1}\right), \mathrm{CFU}_{i}$ : initial colony forming units $\left(\mathrm{CFU} \mathrm{mL}{ }^{-1}\right), S_{0}$ initial substrate concentration $\left(\mathrm{mg} \mathrm{mL}^{-1}\right), S_{f}$ final substrate concentration $\left(\mathrm{mg} \mathrm{mL}^{-1}\right)$. 


\subsubsection{Phosphorous/glucose yield}

$$
Y_{(P / S)}=\frac{P_{f}-P_{i}}{S_{0}-S_{f}}
$$

Where: $Y_{(P / S)}$ is the product yield (soluble P) divided by the substrate (glucose) $\left(\mathrm{mg} \mathrm{mg}^{-1}\right)$, $P_{f}$ is the final product $\left(\mathrm{mg} \mathrm{L}^{-1}\right), P_{i}$ : initial product $\left(\mathrm{mg} \mathrm{L}^{-1}\right), S_{0}$ initial substrate concentration $\left(\mathrm{mg} \mathrm{L}^{-1}\right), S_{f}$ final substrate concentration $\left(\mathrm{mg} \mathrm{L}^{-1}\right)$.

\subsubsection{Biomass phosphorus/glucose productivity $P_{(X)}$}

$$
\text { Biomass Productivity }=\frac{X_{f}-X_{0}}{T}
$$

Where: $X_{f}$ is final biomass $\left(\mathrm{CFU} \mathrm{mL}{ }^{-1}\right), X_{0}$ is the initial biomass $\left(\mathrm{CFU} \mathrm{mL}^{-1}\right), T$ is the time (h) where maximum biomass is achieved.

\subsubsection{Soluble Productivity $P_{(P / S)}$}

$$
\text { Product Productivity }=\frac{P_{f}-P_{0}}{T}
$$

Where: $P_{f}$ is the final product $\left(\mathrm{mg} \mathrm{L}^{-1}\right), P_{0}$ is the initial product $\left(\mathrm{mg} \mathrm{L}^{-1}\right), T$ is the time (h) where the highest corresponding product was evidenced, expressed as acidic phosphatase activity, alkaline phosphatase activity or soluble $\mathrm{P}$.

\subsection{Characterization of the bioinoculants produced in MT11B media}

PSB consortia lots were produced in MT11B media and employed to perform new chemical and microbiological assays to assess biomass stability at different temperatures and $\mathrm{pH}$ values. These assessments involved: quantification of volumetric acid and alkaline phosphatase activity, organic acid production, and Calboy ${ }^{\circledR}$ phosphate rock phosphate solubilization with produced organic acids by the consortium. Additionally, phosphate rock was observed at the beginning and at the end of the kinetics to describe the morphology, surface and evidence the formation of bacterial biofilms on the phosphate rock by means of scanning electron microscopy (SEM) coupled to energy dispersive X-ray spectroscopy EDS for semi quantitative element analysis (SEM/EDS).

\subsection{Chemical and microbiological characterization}

Total phosphorous (TP, $\mathrm{mg} \mathrm{L}^{-1}$ ) (Hach Company (2007)), soluble phosphorous concentrations ( $\mathrm{mg} \mathrm{L}^{-1}$ ) (Murphy and Riley (1962)) as well as $\mathrm{pH}$ were measured for the bioinoculant produced in MT11B media. The bioinoculant were microbiologically characterized through PSB count and PSB morphotype identification (Angulo-Cortés et al. (2012)).

\subsection{Bioinoculant biomass stability at different temperatures and $\mathrm{pH}$ values}

A new lot of bioinoculant was produced and it was subdivided into aliquots of $20 \mathrm{~mL}$ to assay stability at different temperatures. Subsamples were transferred into $50 \mathrm{~mL}$ sterile tubes and were stored at $(8 \pm 2){ }^{\circ} \mathrm{C},(20 \pm 2){ }^{\circ} \mathrm{C},(30 \pm 2){ }^{\circ} \mathrm{C},(40 \pm 2){ }^{\circ} \mathrm{C}$ and $(50 \pm 2){ }^{\circ} \mathrm{C}$ for $12 \mathrm{~h}$. Then, 
samples were collected to perform serial dilutions and were seeded on SMRS1-PR agar to determine colony-forming units $\left(\mathrm{CFU} \mathrm{mL}{ }^{-1}\right)$. Counts were expressed as biomass stability percentage assuming $100 \%$ as the initial concentration. The culture was centrifuged for $10 \mathrm{~min}$ at $8000 \times g$ to recover the supernatant and to determine the concentration of soluble $\mathrm{P}$ and final $\mathrm{pH}$. A control (MT11B without inoculant) was maintained for $12 \mathrm{~h}$ under the same conditions. The response variables colony-forming units $(\%)$ and soluble $\mathrm{P}$ concentration $\left(\mathrm{mg} \mathrm{L}^{-1}\right)$ were measured. Soluble phosphate concentration corresponded to the subtraction of treatment soluble $\mathrm{P}$ minus its control.

A pH stability assay was conducted. The bioinoculant was subdivided into aliquots of $10 \mathrm{~mL}$ and transferred in triplicate into $15 \mathrm{~mL}$ sterile tubes. A given subsample was adjusted, employing $0.1 \mathrm{M} \mathrm{HCl}$ and $0.1 \mathrm{M} \mathrm{NaOH}$, to an initial $\mathrm{pH}$ of $3.0 \pm 0.2,4.0 \pm 0.2,5.0 \pm 0.2,6.0 \pm 0.2$ and $7.0 \pm 0.2$. Each triplicate was stored for $12 \mathrm{~h}$ at $19^{\circ} \mathrm{C}$, and employed thereafter to measure the set of response variables evaluated for biomass stability at different temperatures.

Statistical analyses were performed for biomass stability at different temperatures and $\mathrm{pH}$ values via ANOVA and multiple Tukey comparisons. Data were analyzed using Minitab ${ }^{\circledR}$ (Minitab 18. Ink. 2018, Version 18.0).

\subsection{Acid and alkaline phosphatase activities}

The protocol described by Tabataba and Bremner (1969), with a modification by Rodríguez et al. (2009), was used to determine phosphatase activity. Two sets of tubes were used, one set for acid phosphatases ( $\mathrm{pH} 6.5 \pm 0.2$ ) and another for alkaline phosphatases ( $\mathrm{pH} 11.0 \pm 0.2)$. The bioinoculant was centrifuged at $3578 \times g$ for $20 \mathrm{~min}$ at $19^{\circ} \mathrm{C}$. The supernatant was collected and filtered through Vivaflow 200 Hydrosart cartridges of $100000 \mathrm{Da}$ and $10000 \mathrm{Da}$ to concentrate present phosphatases. Next, $200 \mu \mathrm{L}$ of the concentrated supernatant were transferred into a sterile Eppendorf tube to which $150 \mu \mathrm{L}$ of $0.1 \mathrm{M} p$-nitrophenyl phosphate (prepared in universal MUB buffer at $6.5 \pm 0.2$ and MUB at $\mathrm{pH} 11.0 \pm 0.2$ ) were added. Tubes were then incubated at $37^{\circ} \mathrm{C}$ for $1 \mathrm{~h}$. After incubation, to stop the reaction $100 \mu \mathrm{L} 0.5 \mathrm{M} \mathrm{CaCl}_{2}$ and $400 \mu \mathrm{L} 0.5 \mathrm{M}$ $\mathrm{NaOH}$ were added and centrifuged at $3578 \times g$ for $10 \mathrm{~min}$ at $19^{\circ} \mathrm{C}$. Subsequently, absorbance was read at $\lambda_{400 \mathrm{~nm}}$ in a Genesis-20 spectrophotometer. Absorbances of the triplicates were transformed into concentration using a $p$-nitrophenyl standard curve for acid phosphatases $\left(0.000 \mu \mathrm{mol} \mathrm{mL} \mathrm{m}^{-1}\right.$ to $0.144 \mu \mathrm{mol} \mathrm{mL} \mathrm{m}^{-1}$, Equation: $\left.y=8.6992 x, R^{2}=0.9990\right)$ and a standard curve for alkaline phosphatases $\left(0.000 \mu \mathrm{mol} \mathrm{mL}{ }^{-1}\right.$ to $0.144 \mu \mathrm{mol} \mathrm{mL}^{-1}$, Equation: $y=8.7726 x$, $\left.R^{2}=0.9990\right)$. For this assay one phosphatase unit (1 PU) was the equivalent of $1 \mu \mathrm{mol} \mathrm{min}{ }^{-1} \mathrm{~L}^{-1}$ of $p$-nitrophenyl released under reaction conditions (Tabataba and Bremner (1969); Rodríguez et al. (2009)).

\subsection{Organic acid quantification by HPLC}

To identify and quantify organic acids produced in the MT11B culture medium, $20 \mathrm{~mL}$ of the previously centrifuged culture medium was collected and centrifuged for $20 \mathrm{~min}$ at $3578 \times \mathrm{g}$. These were then filtered through a $0.25 \mu \mathrm{m}$ membrane and injected into a high-resolution liquid chromatography HPLC. A SH111 column was used with $0.01 \mathrm{~N} \mathrm{H}_{2} \mathrm{SO}_{4}$ as the mobile phase. The flow rate was maintained at $0.6 \mathrm{~mL} \mathrm{~min}^{-1}$ at $35^{\circ} \mathrm{C}$. Organic acids were identified by comparing their retention times and areas under the curve, from their chromatograms, with known standards (Cisneros-Rojas et al. (2017); Mardad et al. (2014); Swetha and Padmavathi (2016)). 


\subsection{Phosphate rock solubilization by organic acids}

Phosphate rock solubilization was assayed with gluconic-, oxalic-, citric-, malic- and succinic-acid. The concentration of each acid was established according to their production in the MT11B medium after $6 \mathrm{~h}$ of consortium culture. A total of $9 \mathrm{mg}$ of Calboy ${ }^{\circledR}$ phosphate rock as a source of $\mathrm{P}$ and $3 \mathrm{~mL}$ of each of the organic acid solutions were mixed in $10 \mathrm{~mL}$ glass flaks. All five assays were shaken at $180 \mathrm{rpm}$ and $25^{\circ} \mathrm{C}$ by $60 \mathrm{~min}, 120 \mathrm{~min}$, or $180 \mathrm{~min}$; after which soluble $\mathrm{P}$ concentration $\left(\mathrm{mg} \mathrm{L}^{-1}\right)$ was determined in each of the assays (Murphy and Riley (1958)). Each assay was performed in triplicate.

\subsection{Scanning Electron Microscopy}

Phosphate rock morphology and surface features before and after culture with PSB were observed via scanning electron microscopy (SEM). The predominant chemical elements were determined by element microanalysis through energy dispersive X-ray spectroscopy (EDS) with a JEOL SEM microscope JSM 6490-LV model at a voltage range from $10 \mathrm{kV}$ to $20 \mathrm{kV}$ and $1000 \times$ to $10000 \times$ magnification. The first sample corresponded to commercial phosphate rock before being added to the MT11B medium. The second sample corresponded to the bioinoculant after $6 \mathrm{~h}$ of production, centrifuged for $20 \mathrm{~min}$ at $3578 \times \mathrm{g}$. The recovered sediment was dried at $30^{\circ} \mathrm{C}$. Before analyses, samples were sputter coated with gold under vacuum conditions using a vacuum Desk IV sputter coater with one cycle of coating.

\subsection{Evaluation of the effect of the bioinoculant with an organic mineral fertilizer in a soil planted with onion.}

The effect of a commercial organic mineral fertilizer with and without the bioinoculant in a soil planted with onion was evaluated in the locality of Tópaga (Boyacá, Colombia). In this locality, environmental temperature varies daily from $6^{\circ} \mathrm{C}$ to $17^{\circ} \mathrm{C}\left(5^{\circ} 46^{\prime} 4^{\prime \prime} \mathrm{N}\right.$ and $\left.72^{\circ} 49^{\prime} 54^{\prime \prime} \mathrm{W}\right)$. Soil initial characterization results, were published in a previous study, where the extractable $\mathrm{P}$ of the soil at the time of sowing was $250 \mathrm{mg} \mathrm{kg}^{-1}$ (Blanco-Vargas et al. (2020)). For each treatment, 40 onion seedlings (standard Granex variety) of 2 months of age were sown. The commercial organic mineral fertilizer Abundagro ${ }^{\circledR}$ was then applied in the following doses: $200 \mathrm{~kg} \mathrm{ha}^{-1}$, $170 \mathrm{~kg} \mathrm{ha}^{-1}, 130 \mathrm{~kg} \mathrm{ha}^{-1}, 100 \mathrm{~kg} \mathrm{ha}^{-1}, 70 \mathrm{~kg} \mathrm{ha}^{-1}$ and $50 \mathrm{~kg} \mathrm{ha}^{-1}$. The fertilizer was applied in equal concentration fractions at three different times: when the plant was transplanted, one month after transplantation, and two months after transplantation. The bioinoculant was applied at $10 \times 10^{7} \mathrm{CFU} \mathrm{mL}{ }^{-1}$ in volumes of $50 \mathrm{~mL} \mathrm{ha}^{-1}$ to $750 \mathrm{~mL} \mathrm{ha}^{-1}$ to half of the treatments receiving the organic fertilizer and to one treatment without fertilizer (henceforth T13) at the three time points described. Water was used as control. Table 2 summarizes the treatments applied.

Before this protocol was started, a physical, chemical, and microbiological characterization of the soil was performed (Okalebo et al. (2002)). Also, the volume of soil saturation was determined by establishing its field capacity, this allowed us to determine the doses of commercial fertilizer and PSB-based bioinoculant to be employed.

Five months after the transplant was performed 10 plants were selected at random to determine the height of the bulb (BH in $\mathrm{cm}$ ), the diameter of the bulb (BD in $\mathrm{cm}$ ), dry weight of the bulb (DWB in g) after drying for 8 days at $30^{\circ} \mathrm{C}$ (Jayathilake et al. (2006)) and total phosphorus in the bulb (TP in $\mathrm{mg}_{\text {bulb }}{ }^{-1}$ ), (Mohamed et al. (2014)). Likewise, five samples were collected from the soil for each treatment at a depth between $0 \mathrm{~cm}$ and $20 \mathrm{~cm}$. Phosphate solubilizing bacteria counts and soluble P concentrations were determined (Murphy and Riley (1958)). For each of the 
Table 2: Treatments for onion field experiments.

\begin{tabular}{|c|c|}
\hline TREATMENT & ABUNDAGRO AND BIOINOCULANT DOSAGE \\
\hline 1 & 200 kg ha-1Abundagro ${ }^{\circledR}+50 \mathrm{~mL}$ PSB \\
\hline 2 & $170 \mathrm{~kg}$ ha-1Abundagro ${ }^{\circledR}+150 \mathrm{~mL}$ PSB \\
\hline 3 & $130 \mathrm{~kg}$ ha-1Abundagro ${ }^{\circledR}+350 \mathrm{~mL}$ PSB \\
\hline 4 & $100 \mathrm{~kg}$ ha-1 Abundagro ${ }^{(\mathbb{R})}+500 \mathrm{~mL}$ PSB \\
\hline 5 & $70 \mathrm{~kg}$ ha-1 Abundagro ${ }^{\circledR}+650 \mathrm{~mL}$ PSB \\
\hline 6 & 50 kg ha-1Abundagro $\left.{ }^{(}\right)+750 \mathrm{~mL}$ PSB \\
\hline 7 & 200 kg ha-1Abundagro ${ }^{\circledR}$ \\
\hline 8 & 170 kg ha-1Abundagro ${ }^{\circledR}$ \\
\hline 9 & 130 kg ha-1Abundagro ${ }^{\circledR}$ \\
\hline $\mathbf{1 0}$ & 100 kg ha-1 Abundagro ${ }^{\circledR}$ \\
\hline 11 & 70 kg ha-1 Abundagro ${ }^{(R)}$ \\
\hline 12 & 50 kg ha-1Abundagro ${ }^{\circledR}$ \\
\hline 13 & $1000 \mathrm{~mL}$ PSB \\
\hline 14 & Control \\
\hline
\end{tabular}

evaluated variables an ANOVA was performed and multiple comparisons were performed via Tukey post hoc tests. Data analysis was carried out with $\mathrm{R}^{\circledR}$ statistical software (StatR, plataform R Wizard Version 2.0) and Minitab ${ }^{\circledR}$ (Minitab 18. Ink. 2018, Version 18.0).

\subsection{Ethical and legal considerations.}

Phosphate solubilizing bacteria employed in this study were isolated following Resolution No. 00778 of 2017 "Framework Permit for wild species collection of specimens of biological diversity for non-commercial scientific research purposes granted to the Pontificia Universidad Javeriana by the Ministry of Environment and Sustainable Development". The mobility permit number was 2018033275-1-000 and 2019133895-1-000.

\section{Results}

\subsection{Soil sampling and isolation of phosphate solubilizing bacteria}

Through the soil screening for PSB conducted in this study, we obtained 52 strains with phosphate solubilizing activity. PSB counts ranged from $4 \times 10^{8} \mathrm{CFU} \mathrm{g}^{-1}$ to $1 \times 10^{5} \mathrm{CFU} \mathrm{g}^{-1}$ without significant differences $(p>0.05)$ among soil sampling cores in both farms. Likewise, large coefficients of variation $(\mathrm{CV})$ were observed in both sampling sites, Punta Larga $(\mathrm{CV}=13.79 \%)$ and Pesca $(\mathrm{CV}=16.45 \%)$; this is probably due to the number of core samplings. Soil's pH was the least variable parameter between sampling sites $(\mathrm{CV}=3.6 \%)$, with values ranging between 5.1 and 8.3.

Autocorrelation results using Moran's I measurements revealed significance only in PSB variables $(p=0.0428)$ and $\mathrm{pH}(p=0.0492)$ in the site Punta Larga. No autocorrelation was observed for the Pesca farm $(p>0.05)$. Hence, it was not possible to perform spatial distribution variograms. Punta Larga's PSB and $\mathrm{pH}$ spatial variability is illustrated in Figure 1, using the Kriging interpolation method, where the effective spatial dependence distance was up to $14 \mathrm{~m}$ from each sampling point. 


\subsection{Selection of phosphate solubilizing bacteria for consortium establishment}

Sample collections in both farms resulted in the obtention of 52 PSB isolates. These isolates were cultured in SMRS1 agar, substituting tricalcium phosphate with phosphate rock. Subsequently, the three bacterial genera with the highest solubilizing potential were identified (Suppl. 1.) The bacteria Pseudomonas sp., Serratia sp., and Kosakonia sp. solubilized phosphate from phosphate rock, obtaining $(2.1 \pm 0.2) \mathrm{mm},(2.0 \pm 0.3) \mathrm{mm}$ and $(2.1 \pm 0.2) \mathrm{mm}$, respectively. Concerning the SMRS1-PR media assay, the following soluble $\mathrm{P}$ concentrations were observed $(66.2 \pm 13.4) \mathrm{mg} \mathrm{L}^{-1},(89.5 \pm 4.7) \mathrm{mg} \mathrm{L}^{-1}$ and $(48.2 \pm 9.5) \mathrm{mg} \mathrm{L}^{-1}$, with counts of $9.0 \pm 0.5$, $8.3 \pm 0.9$ and $10.9 \pm 0.5$ logarithmic units at $72 \mathrm{~h}$ of the process for Pseudomonas sp., Serratia sp., and Kosakonia sp., respectively.

No inhibition halos were observed at $48 \mathrm{~h}$ of incubation when these bacteria were co-cultured. Thus, under experimental conditions no antagonism among bacteria was revealed (Suppl. 1). Additionally, the three bacteria were seeded on blood agar and DNAse agar $\left(2.0 \mathrm{~g} \mathrm{~L}^{-1}\right.$ deoxyribonucleic acid) to verify the presence or absence of $\alpha$ - and $\beta$-hemolysis and to assess the presence of deoxyribonucleases. After $24 \mathrm{~h}$ at $30^{\circ} \mathrm{C}$ the bacteria failed to grow on blood agar and none of them revealed $\beta$-hemolysis or DNAse activity DNAse agar (clear halos were not observed around the colonies) (Figure 2).

\subsection{MT11B culture media design for biomass production}

Phosphate solubilizing bacteria counts were significant $(p=0.0101)$ according to ANOVA analysis; therefore, the effects of different factors were analyzed on this response variable. The Adj $R$-Squared was 0.7396 , with an $R^{2}$ value of 0.8598 . Moreover, Adq. Precision was 6.0. The lack of fit was not significant ( $p=0.8526$ ), suggesting that the model space could be navigated. Significant values, factors (Prob $>f$ ), effects, and contribution percentages for each factor are presented in Table 3.

The factors that influenced PSB counts were time $(p=0.0003)$ and Nitrogen (sourced from brewer's yeast hydrolysate; $p=0.0451$ ). Time had the largest (83.4\%) contribution to PSB counts and was followed by the source of nitrogen $(7.4 \%)$. The effect of time was negative $(-1.77)$, indicating that one could work at its minimum level $(12 \mathrm{~h})$. Additionally, the regression

Table 3: Plackett-Burman design ANOVA analysis for colony forming units expressed as $\log _{10} \mathrm{CFU} \mathrm{mL}^{-1}$.

\begin{tabular}{|l|c|c|c|c|}
\hline \multicolumn{5}{|c|}{ PSB COUNT $\left(\log _{10} \mathrm{CFU} \mathrm{mL}^{-1}\right)$} \\
\hline \multirow{2}{*}{ FACTOR } & \multirow{2}{*}{$F$-VALUE } & Prob $>f$ & \multirow{2}{*}{ STAND. EFFECT } & \multirow{2}{*}{ \% CONTRIBUTION } \\
\cline { 3 - 5 } & & $p$-VALUE & & \\
\hline Model & 7.6 & 0.0101 & 5.280 & 0.0298 \\
\hline A-PR & 0.015 & 0.9050 & 0.033 & 0.298 \\
\hline B-Glucose & 0,016 & 0.09051 & 0.032 & 7.400 \\
\hline C-Brewers Yeast Hydrolysate & 0.63 & 0.0451 & -0.220 & 0.300 \\
\hline D-Agitation & 0.001 & 1.0000 & 0.001 & 0.186 \\
\hline E-Inoculum & 0.094 & 0.7680 & 0.083 & \\
\hline F: Time & 42.1 & 0.0003 & -1.770 & \\
\hline R2 & 0.8598 & & & \\
\hline Adj R-Squared & 0.7396 & & & \\
\hline Adq. precision & 6.0 & & & \\
\hline Lack of Fit & 0.8526 & & & \\
\hline
\end{tabular}




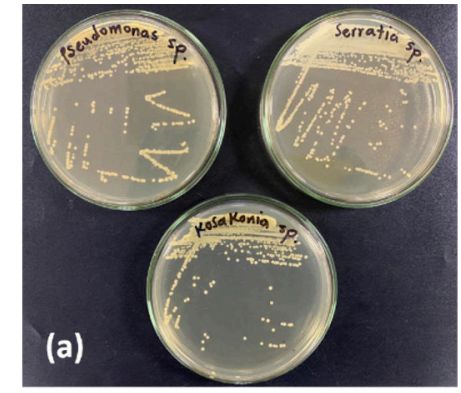

Bacteria in $\mathrm{BH}$ I Agar Reactivation

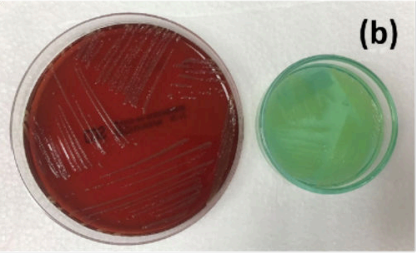

Kosakonia sp. in Blood and DNase Agar

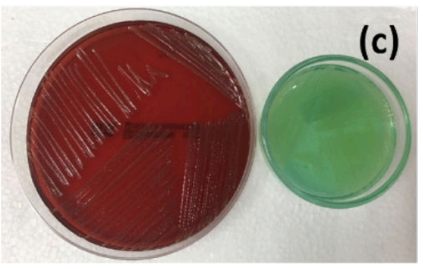

Pseudomonas sp. in Blood and DNase Agar Pseudomonas sp. with Transilluminator

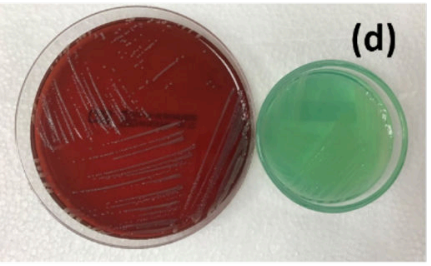

Serratia sp. in Blood and DNase Agar

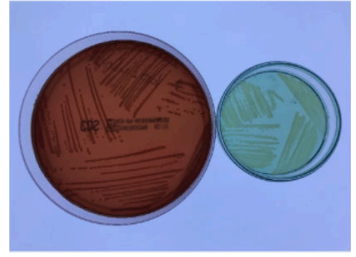

Kosakonia sp. with Transilluminator
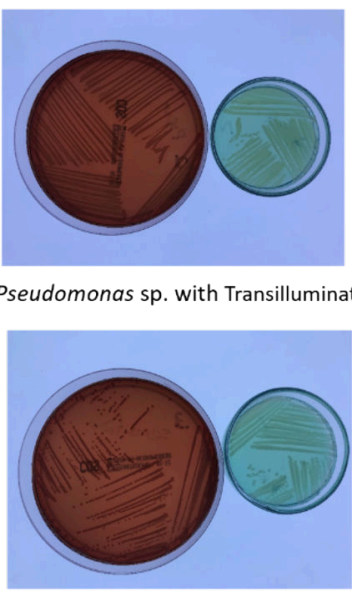

Serratia sp. with Transilluminator
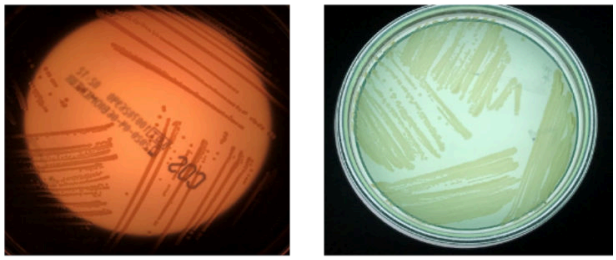

Kosakonia sp. with Stereoscope

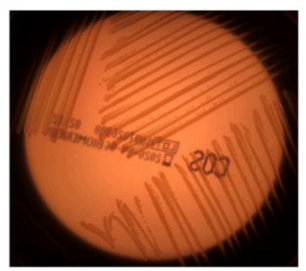

Pseudomonas sp. with Stereoscope

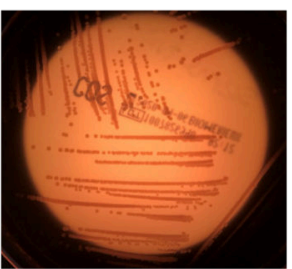

Serratia sp. with Stereoscope
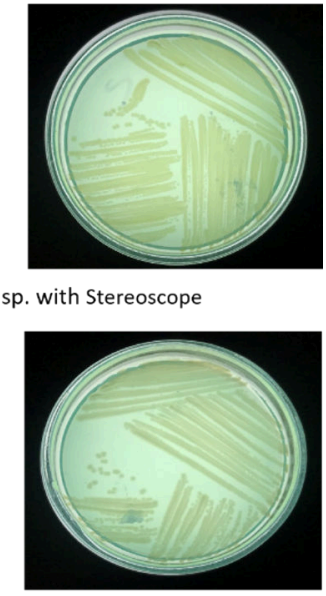

Figure 2: $\beta$-hemolysis and deoxyribonuclease activity verification assay. (a) Reactivation and seeding (by isolation) of Pseudomonas sp., Serratia sp., and Kosakonia sp., on BHI agar, for $24 \mathrm{~h}$ at $37^{\circ} \mathrm{C}$. (b) Kosakonia sp., showing no -hemolytic activity in blood agar or deoxyribonuclease activity in DNAase agar. (c) Pseudomonas sp., showing no $\beta$-hemolytic activity in blood agar and deoxyribonuclease activity in DNAse agar. (d) Serratia sp., showing no $\beta$-hemolytic activity on blood agar and deoxyribonuclease activity on DNAse agar. Photographs in the first column on the left were taken with white light. Photographs in the second column were taken with white backlight using a transilluminator. Photographs in the last two columns on the right were observed in a stereoscope to generate greater definition of colonies and to evidence the absence or presence of small halos of hemolysis and hydrolysis. All boxes were incubated for $24 \mathrm{~h}$ at $37^{\circ} \mathrm{C}$.

coefficient for Nitrogen sourced from brewer's yeast hydrolysate was -0.22 , indicating that the lowest concentration could be used. None of the following had an effect on PSB: PR, glucose, agitation velocity, and inoculum percentage $(p>0.05)$. These could be used both at the low or high level or they could be fixed according to regression coefficient value of each of them (Table 3).

PSB growth on the 12 tested MT11B medium compositions revealed significant $(p<0.0001)$ variation. One of the medium compositions led to the highest colony forming units observed $\left(2 \times 10^{8} \mathrm{CFU} \mathrm{mL} \mathrm{mL}^{-1}\right)$, whereas the other tested medium compositions lead to CFUs values between 
$1 \times 10^{2} \mathrm{CFU} \mathrm{mL} \mathrm{m}^{-1}$ and $1 \times 10^{7} \mathrm{CFU} \mathrm{mL}^{-1}$. The chosen medium composition and conditions for PSB consortium growth were the following: $5.0 \mathrm{~g} \mathrm{~L}^{-1} \mathrm{PR}, 2.5 \mathrm{~g} \mathrm{~L}^{-1}$ glucose, $0.5 \mathrm{~g} \mathrm{~L}^{-1}$ brewer's yeast hydrolysate, $0.5 \mathrm{~g} \mathrm{~L}^{-1}\left(\mathrm{NH}_{4}\right)_{2} \mathrm{SO}_{4}, 0.2 \mathrm{~g} \mathrm{~L}^{-1} \mathrm{KCl}, 0.3 \mathrm{~g} \mathrm{~L}^{-1} \mathrm{MgSO}_{4}, 0.004 \mathrm{~g} \mathrm{~L}^{-1} \mathrm{MnSO}_{4}$ $* 7 \mathrm{H}_{2} \mathrm{O}, 0.0004 \mathrm{~g} \mathrm{~L}^{-1} \mathrm{FeSO}_{4}$, and $0.2 \mathrm{~g} \mathrm{~L}^{-1} \mathrm{NaCl}$, at pH $7.2 \pm 0.2 ; 12 \mathrm{~h}$, at $30^{\circ} \mathrm{C}, 200 \mathrm{rpm}$, and $10 \%(\mathrm{v} / \mathrm{v})$ of inoculum. This medium composition and culture conditions were employed to perform the growth curve and estimation of production kinetic parameters.

As observed in Table 3, a glucose level of $2.5 \mathrm{~g} \mathrm{~L}^{-1}$ was used. However, glucose could be employed in either level, and was deemed as a factor not-affecting PSB growth ( $p=0.09051)$. For T11, at the end of the evaluation time, glucose was not completely consumed, and a residual value of $1.0 \mathrm{~g} \mathrm{~L}^{-1}$ was identified. Nitrogen, sourced from brewer's yeast hydrolysate, was a factor significantly affecting PSB growth $(p=0.0451)$. A nitrogen concertation of $0.5 \mathrm{~g} \mathrm{~L}^{-1}$ was used with a percentage contribution of $7.4 \%$ to obtain a $\mathrm{C} / \mathrm{N}$ ratio of approximately 10 . In this manner, the source of carbon could be rapidly consumed, favoring growth at $12 \mathrm{~h}\left(2 \times 10^{8} \mathrm{CFU} \mathrm{mL}^{-1}\right)$ and decreasing $\mathrm{pH}$ to promote soluble $\mathrm{P}$ release into the culture media, which was verified with final soluble $\mathrm{P}$, residual glucose and $\mathrm{pH}$ quantification obtaining orthophosphate values of $80 \mathrm{mg} \mathrm{L}^{-1}$, $1.1 \mathrm{~g} \mathrm{~L}^{-1}$ glucose and a $\mathrm{pH}$ of $3.0 \pm 0.2$.

Soluble $\mathrm{P}$ production was unaffected by our treatments. At $12 \mathrm{~h}$ of culture in the presence of an inorganic P source with low solubility (i.e., phosphate rock), bacteria were capable of solubilizing $80 \mathrm{mg} \mathrm{L}^{-1}$. Residual glucose in treatment $\mathrm{T} 11$ presented one of the lowest values among all twelve evaluated treatments. This source of carbon was assimilated and produced organic, which decreased the $\mathrm{pH}$. Hence, $\mathrm{pH}$ values lower than $4.0 \pm 0.2$, favored $\mathrm{P}$ solubilization. Soluble $\mathrm{P}$, residual glucose, and $\mathrm{pH}$ results for the remaining treatments evaluated in the Plackett-Burman Design are presented in Suppl. 2.

\subsection{Bioinoculant production and growth curve in MT11B medium}

The PSB consortium's growth curve was performed in the T11 medium. This medium was selected from the PB and named MT11B. A lag phase was not clearly observed (probably due to sampling frequency) and the exponential phase was prolonged from 0 up to 6 hours, where maximum biomass production was observed with $(10.600 \pm 0.078) \log _{10} \mathrm{CFU} \mathrm{mL}^{-1}$ (Figure 3). A subsequent slight decrease in biomass was observed up to hour 8 with $(10.100 \pm 0.018) \log _{10} \mathrm{CFU} \mathrm{mL}^{-1}$. The stationary phase began at $8 \mathrm{~h}$ of culture and went up to $10 \mathrm{~h}$, when the death phase began and lasted up to hour 12; at this point bacterial count was $(9.700 \pm 0.059) \log _{10} \mathrm{CFU} \mathrm{mL}^{-1}$. Concerning the growth's volumetric velocity $\left(K_{0}\right)$, its determined value up to $6 \mathrm{~h}$ of culture was $(4.4 \pm 0.4) \times 10^{9} \mathrm{CFU} \mathrm{mL}^{-1} \mathrm{~h}^{-1}$ with a doubling time $\left(D_{t}\right)$ of $(0.052 \pm 0.012) \mathrm{h}$ (Table 4).

The initial glucose concentration in MT11B medium was $(2.460 \pm 0.077) \mathrm{g} \mathrm{L}^{-1}$ with a pH of $7.2 \pm 0.2$. When the PSB consortium was inoculated into the sterile medium, its $\mathrm{pH}$ decreased to $5.090 \pm 0.064$. Probably, because of produced metabolites during inoculum preparation. Residual glucose was $(0.98 \pm 0.05) \mathrm{g} \mathrm{L}^{-1}$ and a final $\mathrm{pH}$ of $3.400 \pm 0.025$ (Figure 3).

The highest soluble P (SP) concentrations released by the consortium into the MT11B media were obtained at 4 and $12 \mathrm{~h}$ of production with values of $(55.200 \pm 0.695) \mathrm{mg} \mathrm{L}^{-1}$ and $(53.500 \pm 3.386) \mathrm{mg} \mathrm{L}^{-1}$, respectively. Given that PSB release diffusible metabolites into the medium, such as phosphatases and organic acids to liberate SP, it is safe to assume that PSB count is positively related to the availability of these metabolites and to the amount of $\mathrm{P}$ into the medium. 


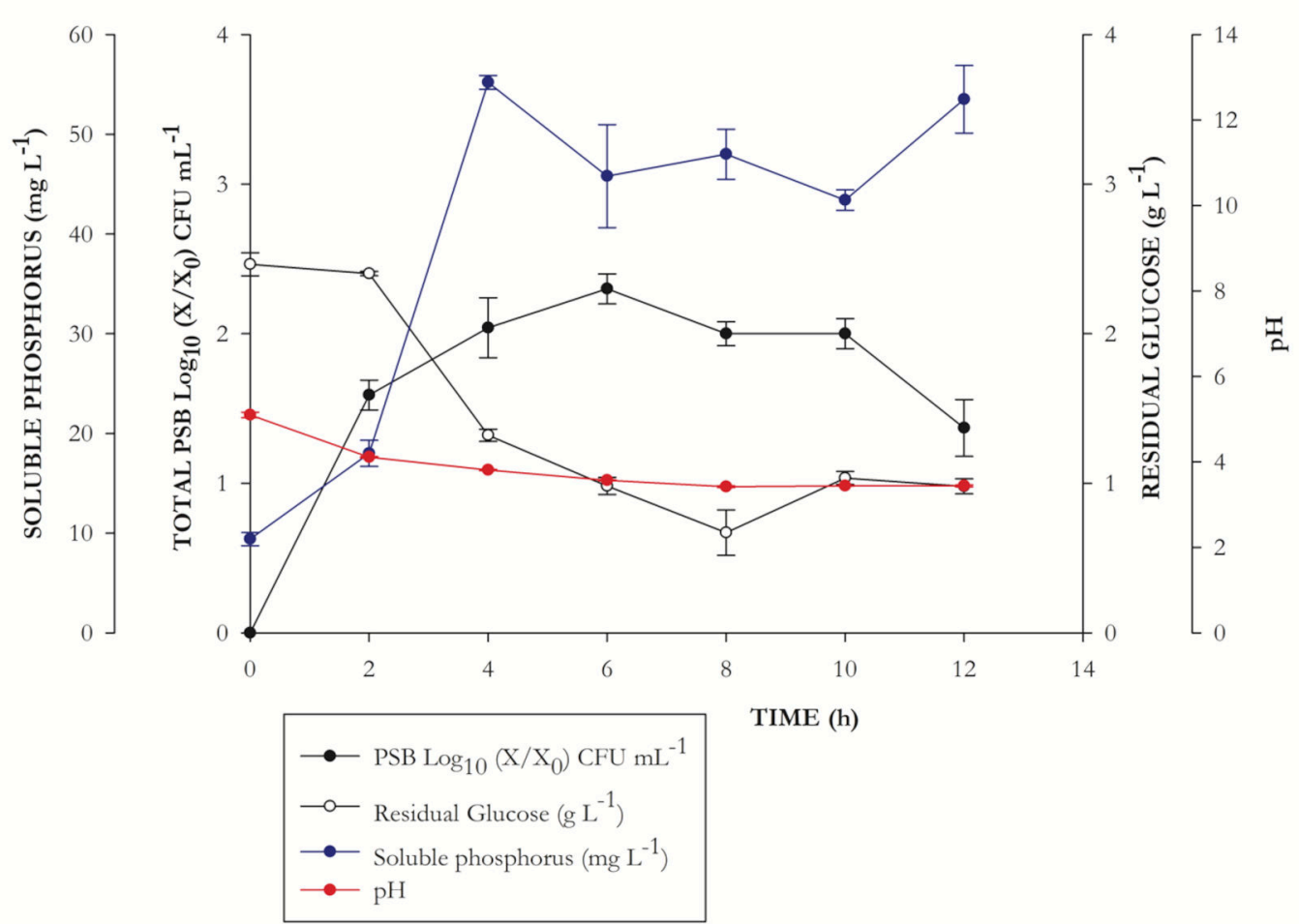

Figure 3: Bioinoculant production and growth its curve in MT11B medium during $12 \mathrm{~h}$ of culture. Operation conditions: $30^{\circ} \mathrm{C}, 200 \mathrm{rpm}$. Results are presented as the mean of three replicas with their respective standard deviation.

To determine the optimal time of bioinoculant production, biomass/substrate yield was calculated. Significant differences were observed $(p<0.05)$ between the evaluated hours; a yield of $(3.0000000 \pm 0.0000004) \times 10^{10} \mathrm{CFU} \mathrm{mL}^{-1} \mathrm{~g}^{-1}$ was obtained at hour 6 , one logarithmic unit higher than that observed at hour $12\left((3.0 \pm 0.5) \times 10^{9} \mathrm{CFU} \mathrm{mL}^{-1} \mathrm{~g}^{-1}\right)$. Soluble $\mathrm{P}$ in glucose was higher at $12 \mathrm{~h}\left((0.048 \pm 0.001) \mathrm{mg} \mathrm{mg}^{-1}\right)$; since at this time point residual glucose content was less than at $6 \mathrm{~h}$ (Table 4). Additionally, biomass production and soluble $\mathrm{P}$ were calculated at hours 6 and 12, obtaining values of $(7.00 \pm 0.01) \times 10^{9} \mathrm{CFU} \mathrm{mL}^{-1} \mathrm{~h}^{-1},(4.0 \pm 0.5) \times 10^{8}$ CFU mL ${ }^{-1} \mathrm{~h}^{-1}$ for biomass, and $(6.9 \pm 1.4) \mathrm{mg} \mathrm{L}^{-1} \mathrm{~h}^{-1}$ and $(4.3 \pm 0.2) \mathrm{mg} \mathrm{L}^{-1} \mathrm{~h}^{-1}$ for soluble

Table 4: Bioinoculant kinetic production parameters in MT11B medium. *ND (Not determined). Results in bold correspond to the highest yield and/or productivity obtained at $6 \mathrm{~h}$ of bioinoculant production in MT11B media. $a$ and $b$ letters represent heterogeneous subsets of Tukeys statistical test with highly significant differences $(p<0.05)$.

\begin{tabular}{|l|l|l|}
\hline \multicolumn{1}{|c|}{ PARAMETER } & MT11B MEDIA AT 6 H & MT11B MEDIA AT 12 H \\
\hline K0 $\left(\mathrm{CFU} \mathrm{mL} \mathrm{m}^{-1} \mathrm{~h}^{-1}\right)$ & $(4.4 \pm 0.4) \times 10^{9}$ & ND* \\
\hline $\mathrm{Dt}(\mathrm{h})$ & $0.052 \pm 0.012$ & $\mathrm{ND}$ \\
\hline $\mathrm{Y}($ Biomass/glucose $)\left(\mathrm{CFU} \mathrm{mL} \mathrm{m}^{-1} \mathrm{~g}^{-1} \mathrm{~L}^{-1}\right)$ & $(3.0 \pm 0.5) \times 10^{10 a}$ & $(3.0 \pm 0.5) \times 10^{9 b}$ \\
\hline $\mathrm{Y}($ Soluble P/glucose $)\left(\mathrm{mg} \mathrm{g}^{-1}\right)$ & $0.032 \pm 0.007^{b}$ & $0.0454 \pm 0.0003^{a}$ \\
\hline $\mathrm{P}$ (biomass) $\left(\mathrm{CFU} \mathrm{mL} \mathrm{m}^{-1} \mathrm{~h}^{-1}\right)$ & $(7.00 \pm 0.01) \times 10^{9 a}$ & $(4.0 \pm 0.5) \times 10^{8 b}$ \\
\hline $\mathrm{P}($ Soluble $\mathrm{P})\left(\mathrm{mg} \mathrm{L}^{-1} \mathrm{~h}^{-1}\right)$ & $6.9 \pm 1.4^{a}$ & $4.5 \pm 0.3^{b}$ \\
\hline $\mathrm{P}($ acid phosphatase $)\left(\mathrm{PU} \mathrm{h}^{-1}\right)$ & $0.380 \pm 0.013$ & $\mathrm{ND}$ \\
\hline $\mathrm{P}$ (alkaline phosphatase $)\left(\mathrm{PU} \mathrm{h}^{-1}\right)$ & $0.625 \pm 0.031$ & $\mathrm{ND}$ \\
\hline
\end{tabular}


$\mathrm{P}$, respectively. Acid phosphatase and alkaline phosphatase productivity were determined for the hour with the highest biomass production $(6 \mathrm{~h})$ obtaining values of $(0.380 \pm 0.013) \mathrm{U} \mathrm{L}^{-1} \mathrm{~h}^{-1}$ and $(0.625 \pm 0.031) \mathrm{U} \mathrm{L}^{-1} \mathrm{~h}^{-1}$ (Table 4$\left.)\right)$.

\subsection{Bioinoculant production characterization in MT11B medium}

Bioinoculant microbiological and chemical characterizations are presented in Table 5. The concentration of PSB in the bioinoculant was of $1.1 \times 10^{13} \mathrm{CFU} \mathrm{mL}^{-1}$, and PSB counts by morphotype were roughly similar for Pseudomonas sp., Serraria sp., and Kosakonia sp, with $6.2 \times 10^{12} \mathrm{CFU} \mathrm{mL}^{-1}, 3.3 \times 10^{12} \mathrm{CFU} \mathrm{mL}^{-1}$ and $5.0 \times 10^{11} \mathrm{CFU} \mathrm{mL}^{-1}$, respectively. Acid phosphatase and Alkaline phosphatase activities at 12 hours of production were $(2.300 \pm 0.076)$ PU and (3.800 \pm 0.133$) \mathrm{PU}$, respectively. The concentrations of total phosphorus and soluble phosphorus were $354 \mathrm{mg} \mathrm{L}^{-1}$ and $(45.800 \pm 5.170) \mathrm{mg} \mathrm{L}^{-1}$.

\subsection{Bioinoculant stability under variable temperature and $\mathbf{p H}$}

Temperature and $\mathrm{pH}$ affected bioinoculant stability. Within the temperature range of $(8 \pm 2)^{\circ} \mathrm{C}$ and $(30 \pm 2)^{\circ} \mathrm{C}$ the bioinoculant was stable, revealing bacterial population stability percentages above $80 \%$ (Figure 4a). PSB in the bioinoculant were less sensitive within the $\mathrm{pH}$ range of 4.0 to 6.0. However, bacterial population stability percentages within this $\mathrm{pH}$ range were below $68 \%$ (Figure 4c).

PSB counts differed significantly with temperature, as revealed by ANOVA ( $p=0.0000)$. The initial PSB count was of $(10.600 \pm 1.078) \log _{10} \mathrm{CFU} \mathrm{mL}^{-1}$. Subsequently, PSB stability at $(8 \pm 2){ }^{\circ} \mathrm{C}$ had a count of $(8.600 \pm 0.817) \log _{10} \mathrm{CFU} \mathrm{mL}-1$ (81.13\%), PSB stability at (20 \pm 2$)$ ${ }^{\circ} \mathrm{C}$ had a count of $(10.600 \pm 1.739) \log _{10} \mathrm{CFU} \mathrm{mL}^{-1}(95 \%)$ and PSB stability at $(30 \pm 2){ }^{\circ} \mathrm{C}$ had a count of $(11.600 \pm 0.336) \log _{10} \mathrm{CFU} \mathrm{mL}^{-1}(100 \%)$ (Figure $\left.4 \mathrm{~A}\right)$.

The initial soluble $\mathrm{P}$ concentration in the temperature stability assay was $(35.500 \pm 2.184) \mathrm{mg} \mathrm{L}^{-1}$. Significant differences were observed ANOVA $p=0.0001)$. A Tukey post hoc test revealed higher soluble $\mathrm{P}$ concentrations $\left((54.2 \pm 3.1) \mathrm{mg} \mathrm{L}^{-1},(51.6 \pm 1.7) \mathrm{mg} \mathrm{L}^{-1}\right.$ and $\left.(51.2 \pm 4.2) \mathrm{mg} \mathrm{L}^{-1}\right)$ at temperatures of $(40 \pm 2){ }^{\circ} \mathrm{C},(30 \pm 2){ }^{\circ} \mathrm{C}$ and $(50 \pm 2){ }^{\circ} \mathrm{C}$, namely, respectively (Figure 4B).

The stability of the bacterial population varied with $\mathrm{pH}$ values. The initial PSB count was $(10.500 \pm 0.142) \log _{10} \mathrm{CFU} \mathrm{mL} \mathrm{m}^{-1}$. At $\mathrm{pH}$ values of 4.0 and 6.0, PSB stabilities were of $64 \%$ and $68 \%$, and their respective with PSB counts were of $(6.8 \pm 0.4) \log _{10} \mathrm{CFU} \mathrm{mL}^{-1}$ and

Table 5: Bioinoculant bacterial population, volumetric enzyme activity, and phosphorous concentration in MT11B media.

\begin{tabular}{|c|c|}
\hline COMPOSITION & VALUE \\
\hline Total PSB count & $1.1 \times 10^{13} \mathrm{CFU} \mathrm{mL}^{-1}$ \\
\hline Pseudomonas sp. count & $6.2 \times 10^{12} \mathrm{CFU} \mathrm{\textrm {mL } ^ { - 1 }}$ \\
\hline Serratia sp. Count & $3.3 \times 10^{12} \mathrm{CFU} \mathrm{\textrm {mL } ^ { - 1 }}$ \\
\hline Kosakonia sp. Count & $5.0 \times 10^{11} \mathrm{CFU} \mathrm{mL}^{-1}$ \\
\hline Acid phosphatase activity & $(2.300 \pm 0.076) \mathrm{PU}^{-1}$ \\
\hline Alkaline phosphatase activity & $(3.800 \pm 0.133) \mathrm{PU}^{-1}$ \\
\hline Total phosphorus & $354 \mathrm{mg} \mathrm{L}^{-1}$ \\
\hline Soluble phosphorus & $(45.800 \pm 5.170) \mathrm{mg} \mathrm{L}^{-1}$ \\
\hline $\mathrm{pH}$ & 3.57 \\
\hline
\end{tabular}



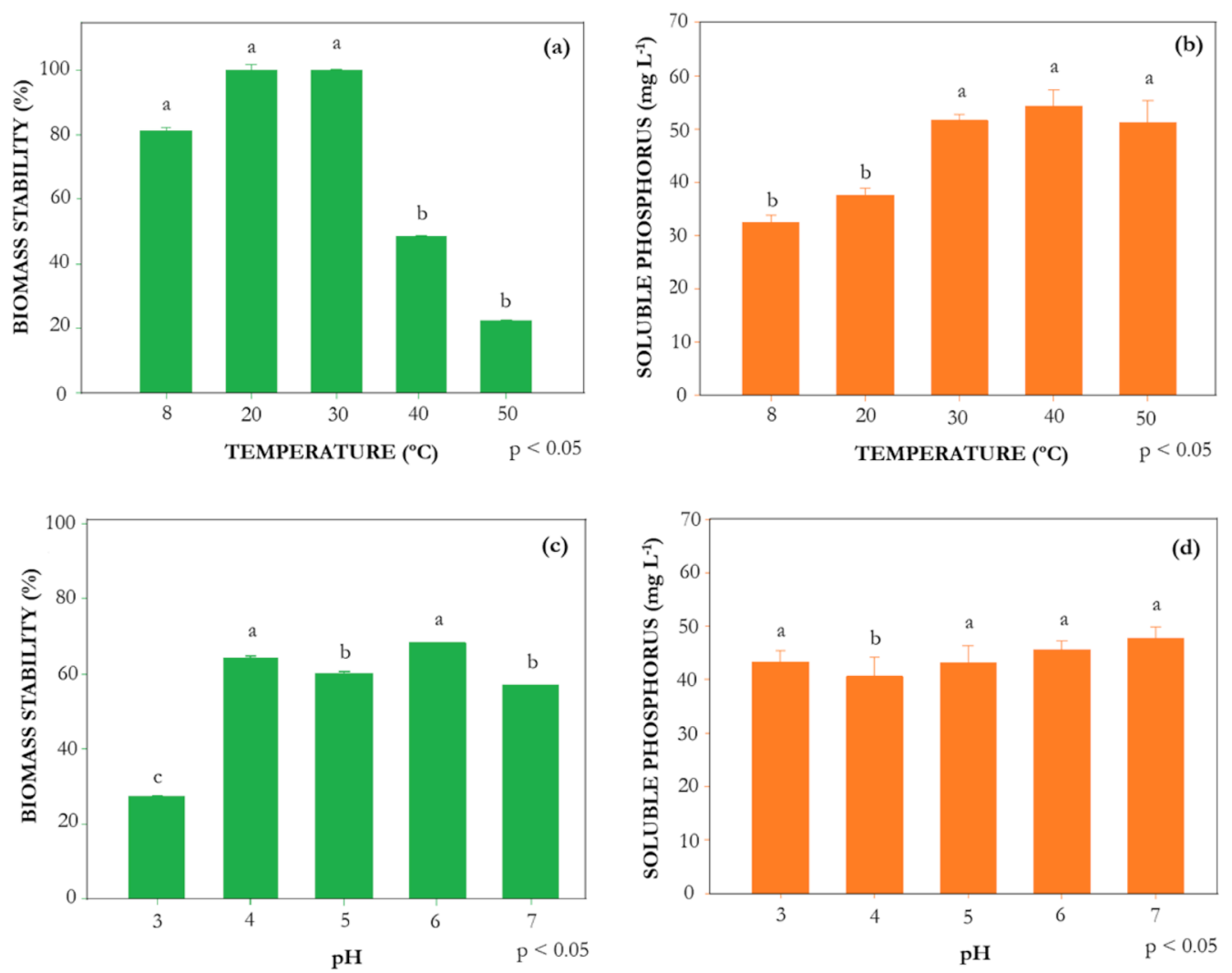

Figure 4: Biomass and soluble $\mathrm{P}$ stability at different temperatures and $\mathrm{pH}$ levels. (a) Biomass stability percentages under variable temperatures. (b) Soluble P concentrations at different temperatures. (c) Biomass stability percentages at different $\mathrm{pH}$ levels. (d) Soluble $\mathrm{P}$ concentrations at different $\mathrm{pH}$ levels. All determinations were performed in triplicate. Letters on bars represent heterogeneous subsets according to Tukey's test with highly significant differences $(p<0.05)$.

(7.2 \pm 0.1$) \log _{10} \mathrm{CFU} \mathrm{mL} \mathrm{m}^{-1}$ (Figure 4C). Collectively, significant differences were observed $(p<0.001)$ with the highest stabilities obtained at $\mathrm{pH}$ values of $4.0 \pm 0.2$ and $6.0 \pm 0.2$. The initial soluble $\mathrm{P}$ concentration in the $\mathrm{pH}$ stability assay was of $(29.5 \pm 2.9) \mathrm{mg} \mathrm{L}^{-1}$, and it differed significantly $(p<0.001)$ with $\mathrm{pH}$, whereby the lowest soluble $\mathrm{P}$ concentration $\left((40.6 \pm 3.5) \mathrm{mg} \mathrm{L}^{-1}\right)$ was observed at $\mathrm{pH} 4.0$ (Figure 4D).

\subsection{Enzyme concentration and volumetric activity}

The bioinoculant was centrifuged and its supernatant collected for enzyme analyses. A supernatant volume of $0.85 \mathrm{~L}$ was required for phosphatase concentration (i.e., enrichment). Acid and alkaline phosphatase activities were of $3.6 \mu \mathrm{mol} \mathrm{L}^{-1} \mathrm{~min}^{-1}$ and $3.0 \mu \mathrm{mol} \mathrm{L}^{-1} \mathrm{~min}^{-1}$, respectively (Figure 5). In the final concentrate, acid phosphatase activity decreased to $2.3 \mu \mathrm{mol} \mathrm{L}{ }^{-1} \mathrm{~min}^{-1}$, whereas alkaline phosphatase activity increased to $3.8 \mu \mathrm{mol} \mathrm{L}^{-1} \mathrm{~min}^{-1}, \mathrm{pH}$ remained stable between $3.6 \pm 0.2$ while the volume decreased to $0.07 \mathrm{~L}$. 


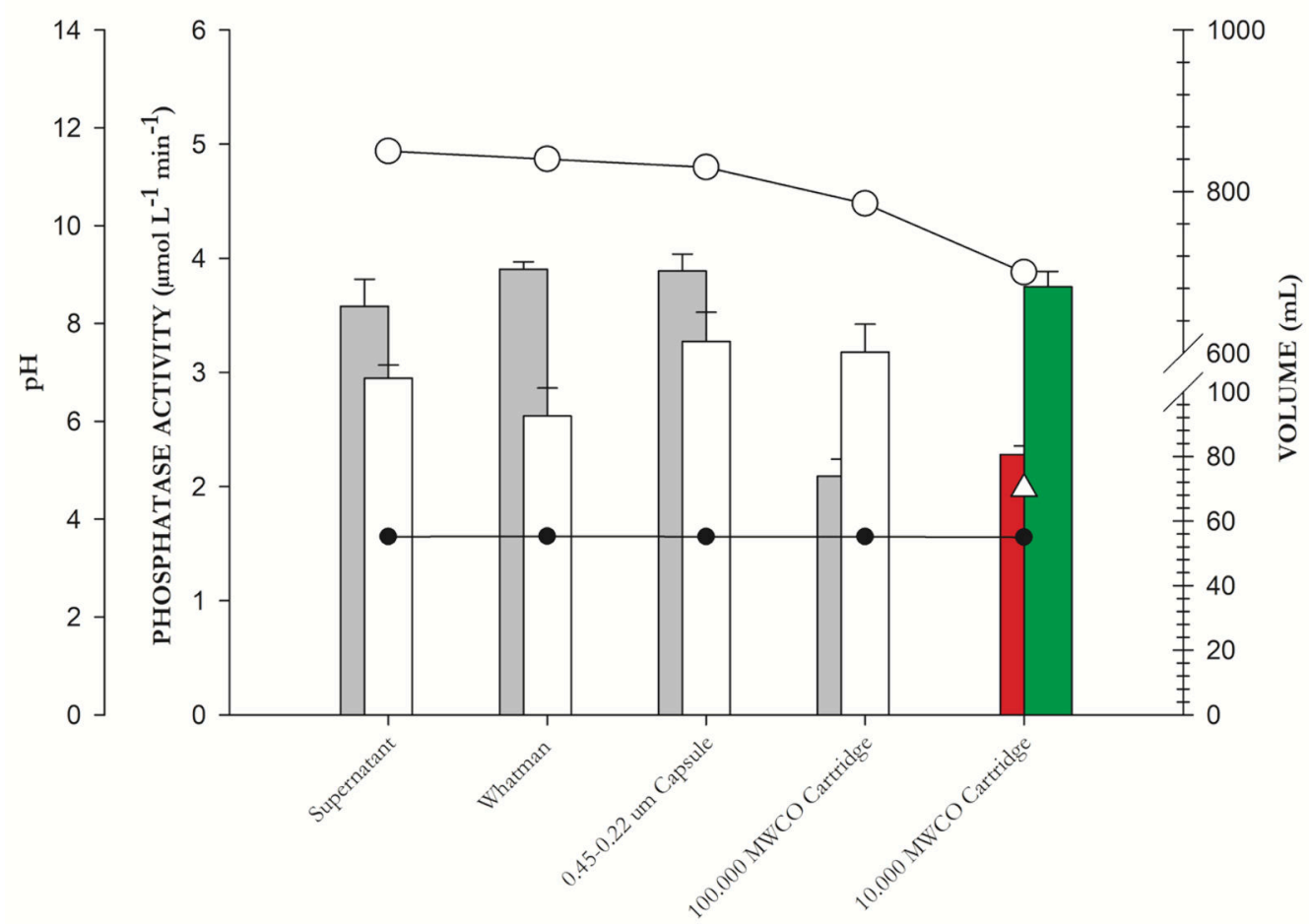

CONCENTRATION STEPS

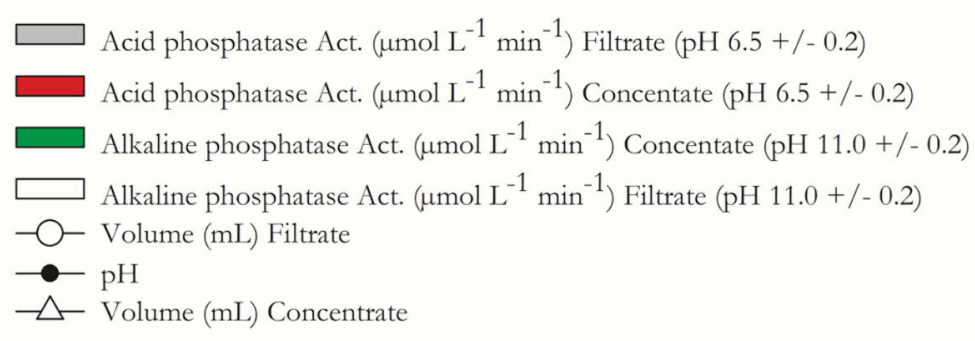

Figure 5: Acid and alkaline phosphatase activity from consortium supernatant concentration.

\subsection{Organic acid production by the consortium}

The organic acids (gluconic-, oxalic-, citric-, malic-, and succinic-acid) produced by the consortium at $6 \mathrm{~h}$ of culture are listed in Table 6. The highest concentration was observed for gluconic acid $\left(682.0 \mathrm{mg} \mathrm{L}^{-1}\right)$, followed by succinic-, malic-, citric-, and oxalic-acids $\left(80.3 \mathrm{mg} \mathrm{L}^{-1}\right.$, $79.2 \mathrm{mg} \mathrm{L}^{-1}, 34.8 \mathrm{mg} \mathrm{L}^{-1}$ and $3.1 \mathrm{mg} \mathrm{L}^{-1}$, respectively). The highest value of soluble P released by commercially purchased organic acids at concentrations produced by the bioinoculant was determined for gluconic acid at 180 minutes (Table 6).

\subsection{Morphological determination and semiquantitative analysis of phosphate rock, with and without PSB}

Morphology and surface characteristics of phosphate rock before being incorporated in the MT11B culture medium, as revealed by SEM magnification of $1000 \times, 6000 \times$ and $10000 \times$, are presented in Figure 6a-c. An irregular surface was observed with granulometry $10 \mu \mathrm{m}>1 \mu \mathrm{m}$. 
Table 6: Table 6. Organic acids produced by the bacterial consortium and soluble $\mathrm{P}$ concentrations released from Calboy ${ }^{\circledR}$ PR mixed with commercially produced organic acids.

\begin{tabular}{|c|c|c|c|c|}
\hline \multirow[t]{2}{*}{ ACID } & \multirow{2}{*}{$\begin{array}{c}\text { ACID CONCENTRATION } \\
\text { PRODUCED BY THE } \\
\text { CONSORTIUM }\left(\mathrm{mg} \mathrm{L}^{-1}\right) \text { AT } 6 \mathrm{H}\end{array}$} & \multicolumn{3}{|c|}{$\begin{array}{c}\text { SOLUBLE P } \\
\text { RELEASED }\left(\mathrm{mg} \mathrm{L}^{-1}\right)\end{array}$} \\
\hline & & $\begin{array}{c}\mathbf{6 0} \\
\text { MINUTES }\end{array}$ & $\begin{array}{c}120 \\
\text { MINUTES }\end{array}$ & $\begin{array}{c}180 \\
\text { MINUTES }\end{array}$ \\
\hline Gluconic & 682.0 & $58.5 \pm 4.0$ & $61.4 \pm 2.3$ & $66.3 \pm 2.6$ \\
\hline Succinic & 80.3 & $20.5 \pm 0.9$ & $22.1 \pm 1.4$ & $27.1 \pm 1.8$ \\
\hline Malic & 79.2 & $28.9 \pm 1.6$ & $27.8 \pm 3.7$ & $29.8 \pm 3.0$ \\
\hline Citric & 34.8 & $18.6 \pm 1.9$ & $21.4 \pm 0.7$ & $31.5 \pm 1.8$ \\
\hline Oxalic & 3.1 & $4.6 \pm 1.2$ & $2.8 \pm 0.6$ & $4.0 \pm 0.5$ \\
\hline
\end{tabular}

After $6 \mathrm{~h}$ of bioinoculant production in MT11B medium with the PSB consortium, bacteria adhered to phosphate rock forming a biofilm (Figure 6d-f). The initial phosphate rock EDS analysis revealed the following values, $\mathrm{C}(9.3 \pm 0.4), \mathrm{O}(52.0 \pm 1.7), \mathrm{Al}(1.0 \pm 0.5), \mathrm{Si}$ (21.0), $\mathrm{P}$ $(10.6 \pm 0.8)$, and $\mathrm{Ca}(23.8 \pm 3.3)$.

\subsection{Effect of Bioinoculant and Abundagro ${ }^{\circledR}$ organic mineral fertilizer on onion growth}

After five months of onion transplant into soils previously treated with an organic mineral fertilizer and the bioinoculant or the organic fertilizer alone, significant differences between treatments were observed for onion bulb height (BH) $(p<0.001)$, bulb diameter (BD) $(p<0.001)$, and dry bulb weight (DBW) $(p<0.001)$. All of the assessed effects of the bioinoculant on onion growth are presented in Table 7. Plants that received an application of $100 \mathrm{~kg} \mathrm{ha}^{-1}$ Abundagro ${ }^{\circledR}$ and $500 \mathrm{~mL}$ bioinoculant (T4) presented the highest values for the evaluated variables $((170.1 \pm 22.2) \mathrm{mm}$ $\mathrm{BH},(49.4 \pm 6.5) \mathrm{mm}$ for BD, and $(9.0 \pm 1.8) \mathrm{g}$ for DBW). In contrast, application of high doses of fertilizer had a negative effect on onion growth, as evidenced in results obtained from treatments 7, 8, and 9 (T7: $(128.4 \pm 18.8) \mathrm{mm}$ for $\mathrm{BH},(37.5 \pm 8.4) \mathrm{mm}$ for $\mathrm{BD}$, and $(4.5 \pm 1.8) \mathrm{g}$ for DBW; T8: $(122.9 \pm 19.9) \mathrm{mm}$ for $\mathrm{BH},(31.8 \pm 6.1) \mathrm{mm}$ for BD, and $(3.3 \pm 1.2) \mathrm{g}$ for DBW; T9: $(120.2 \pm 20.4) \mathrm{mm}$ for $\mathrm{BH},(32.3 \pm 6.8) \mathrm{mm}$ for $\mathrm{BD}$, and $(3.0 \pm 1.1) \mathrm{g}$ for $\mathrm{DBW})$. The results of these treatments were even lower than those where only bioinoculant was applied.

Table 7: Effect of Abundagro ${ }^{\circledR}$ organic fertilizer and phosphate solubilizing bacteria use on onion (A. cepa L.) growth. ND (Not Determined). Letters on superscripts represent heterogeneous subsets of Tukey statistical test with highly significant differences $(p<0.05)$.

\begin{tabular}{|c|c|c|c|c|}
\hline TREATMENT & BULB HEIGHT $(\mathrm{mm})$ & BULB DIAMETER $(\mathrm{mm})$ & BULB DRY WEIGHT (g) & $\begin{array}{c}\text { TOTAL PHOSPHORUS (TP) IN BULB } \\
\mathrm{mg}^{*}\end{array}$ \\
\hline $\mathrm{T} 1$ & $142.4 \pm 27.1^{c}$ & $47.8 \pm 6.7^{b}$ & $6.2 \pm 2.2^{b}$ & 16.86 \\
\hline $\mathrm{T} 2$ & $140.3 \pm 28.1^{d}$ & $46.9 \pm 6.5^{b}$ & $4.4 \pm 2.5^{e}$ & 10.21 \\
\hline $\mathrm{T} 3$ & $139.5 \pm 25.0^{d}$ & $48.2 \pm 8.8^{b}$ & $5.6 \pm 1.2^{c}$ & 9.46 \\
\hline $\mathrm{T} 4$ & $170.1 \pm 22.2^{a}$ & $49.4 \pm 6.5^{a}$ & $9.0 \pm 1.8^{a}$ & 15.21 \\
\hline $\mathrm{T} 5$ & $163.5 \pm 34.3^{b}$ & $42.5 \pm 10.6^{c}$ & $6.4 \pm 2.9^{b}$ & 7.94 \\
\hline $\mathrm{T} 6$ & $132.3 \pm 20.5^{e}$ & $32.7 \pm 8.1^{d}$ & $4.0 \pm 2.3^{e}$ & 12.47 \\
\hline $\mathrm{T} 7$ & $128.4 \pm 18.8^{e}$ & $37.5 \pm 8.4^{c}$ & $4.5 \pm 1.8^{d}$ & 9.44 \\
\hline $\mathrm{T} 8$ & $122.9 \pm 19.9^{e}$ & $31.8 \pm 6.1^{d}$ & $3.3 \pm 1.2^{e}$ & ND \\
\hline $\mathrm{T} 9$ & $120.2 \pm 20.4^{e}$ & $32.3 \pm 6.8^{d}$ & $3.0 \pm 1.1^{e}$ & 16.43 \\
\hline $\mathrm{T} 10$ & $133 \pm 281^{c}$ & $38.5 \pm 7.8^{c}$ & $6.6 \pm 3.1^{b}$ & 11.11 \\
\hline $\mathrm{T} 11$ & $142.7 \pm 22.7^{c}$ & $37.9 \pm 9.6^{c}$ & $5.5 \pm 2.6^{d}$ & 3.37 \\
\hline $\mathrm{T} 12$ & $106.0 \pm 13.4^{e}$ & $24.7 \pm 4.2^{e}$ & $2.2 \pm 0.9^{f}$ & 8.75 \\
\hline $\mathrm{T} 14$ & $141.3 \pm 22.6^{d}$ & $45.3 \pm 8.4^{b}$ & $7.5 \pm 1.7^{c}$ & 2.13 \\
\hline
\end{tabular}



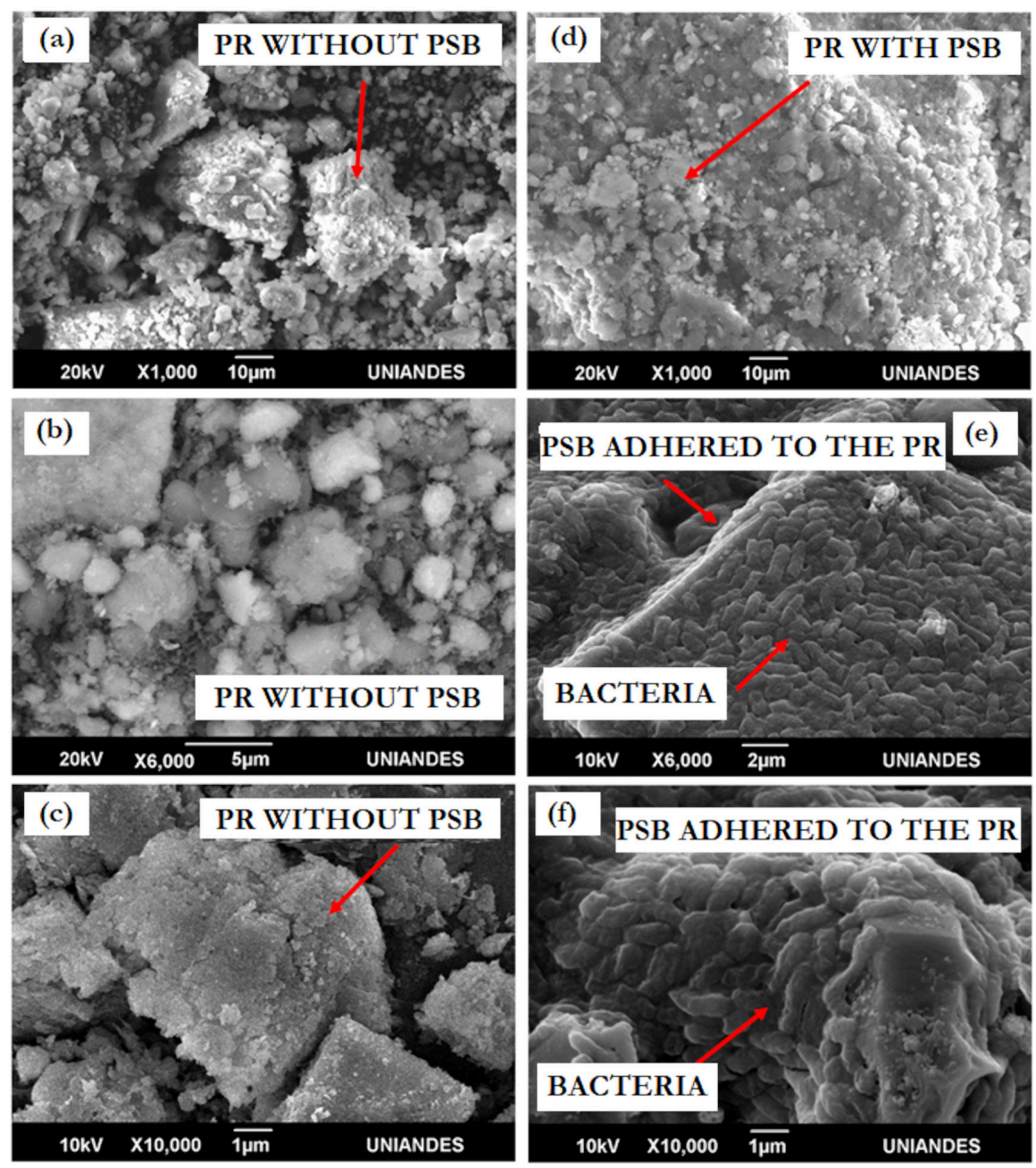

Figure 6: Phosphate rock (PR) before and after PSB treatment. (a), (b), and (c) SEM of initial PR without PSB at three different magnifications $(1000 \times, 6000 \times$, and $10000 \times)$. (d), (e), and (f) PR after $6 \mathrm{~h}$ of treatment in MT11B medium containing PSB at three different magnifications.

In general, bulb $\mathrm{P}$ content and the $\mathrm{BD}$ of onions grown with organic fertilizer + bioinoculant were higher than in bulbs that only received organic fertilizer. It is noteworthy the highest BD was recorded in onions that only received bioinoculant $\left(\mathrm{T} 13=8.75 \mathrm{mg} \mathrm{bulb}^{-1}\right)$. The treatments leading to the highest bulb P content values corresponded to organic fertilizer doses of $200 \mathrm{~kg} \mathrm{ha}^{-1}$ with bioinoculant $\left(\mathrm{T} 1=16.86 \mathrm{mg} \mathrm{bulb}^{-1}\right)$ and $100 \mathrm{~kg} \mathrm{ha}^{-1}$ with and without bioinoculant $\left(\mathrm{T} 10=16.43 \mathrm{mg} \mathrm{bulb}^{-1} ; \mathrm{T} 4=15.21 \mathrm{mg} \mathrm{bulb}^{-1}\right.$, respectively). In contrast, plants under treatments with the lowest doses of organic fertilizer, with and without bioinoculant, presented the lowest values for bulb P content $\left(\mathrm{T} 6=7.74 \mathrm{mg} \mathrm{bulb}^{-1}\right.$ and $\left.\mathrm{T} 12=3.37 \mathrm{mg} \mathrm{bulb}^{-1}\right)$.

At the end of the experiment, extractable and soluble P contents in the soil of treatment T4 were $239 \mathrm{mg} \mathrm{kg}^{-1}$ and $1.36 \mathrm{mg} \mathrm{kg}^{-1}$, respectively; whereas in the soil with the same fertilizer dose and without PSB, the extractable P content reached only $0.21 \mathrm{mg} \mathrm{kg}^{-1}$. 


\section{Discussion}

\subsection{Soil sampling and isolation of phosphate solubilizing bacteria}

Geostatistic techniques, as components of Geographic Information System (GIS) applications, are frequently used for soil mapping and are useful to determine different physical and chemical soil parameter variables in terms of time and geographical location. Our assessment at site Punta Larga revealed significant autocorrelation of two variables (PSB and $\mathrm{pH}$ ), hence with spatial dependence. In contrast, at site Pesca all soil sampled sites revealed complete independence of these variables (Figure 1). This information is of relevance for similar future studies carried in our assessed zone since the spherical model established that this spatial dependence was up to $14 \mathrm{~m}$ between soil cores. To determine microbiological parameters for the Pesca farm, a larger number of soil cores must be considered. Furthermore, the distances between sampling sites should be decreased. Few studies have estimated microbiological variability in soils by using these techniques. However, the resolution level and data reliability make these analyses attractive for the agricultural sector.

Moreover, thanks to the total number of 37 soil samples, a larger number of bacteria native and uniquely adapted to the soils assessed can be isolated. Bacteria from these vey soils are less likely to compete with other microorganisms and are more prone to establishment when brought back, as a bioinoculant, in the source soils. Bioinoculants with native strains are developed from one or various strains. However, bioinoculants consisting of co-cultures or consortia are more attractive, because they can execute multiple and complementary biological activities, whereby maximizing their benefit for the soil and existing plants. Nevertheless, screening techniques must be employed to select for a greater bioinoculant potential.

\subsection{Phosphate solubilizing bacteria selection and identification}

Bioinoculant production and their acceptance by farmers are tightly related. Agricultural practices promote the development of new goods, which in turn time promote technological innovations, tending to maximize revenue (Grageda-Cabrera et al. (2012)). For a bioinoculant to be accepted, it is necessary to guarantee the its quality and biologically stability (Sharma et al. (2013)). Moreover, bioinoculants must deliver the outcome for which they were designed and exclude microorganisms pathogenic to humans, plants, or animals (ICONTEC (2011a,b)). The efficiency of microorganism composing the bioinoculant is pivotal for the production of biological goods. Therefore, strain selection is a primary criterion in the development of bioinoculants (Zambrano-Moreno et al. $(2015 a, b))$.

As observed in Suppl. 1, from the total of 37 soil samples collected, 52 PSB colonies were recovered. This number is too high to establish a single bioinoculant. Hence, when selection assays were performed, the number was reduced to three strains with cell counts $>1.0 \times 10^{7} \mathrm{CFU} \mathrm{mL}^{-1}$. In addition, these selected bacterial strains released over $48 \mathrm{mg} \mathrm{L}^{-1}$ of soluble $\mathrm{P}$, and were not antagonistic among them, thus, meeting the purposes of our study.

Hemolysis can manifest itself in three different ways: alpha $(\alpha)$, when there is partial lysis of the red blood cell membrane, producing a green or brown discoloration at the culture media; beta $(\beta)$, associated with a complete lysis of the red blood cells in which a yellow or transparent halo is produced around the colony and gamma $(\gamma)$, which indicates the absence of hemolysis (Savardi et al. (2018)). The bacteria in this study did not show DNAse activity, which indicates their inability to produce enzymes to hydrolyze DNA. Neither, areas of clearance were obtained by hemolysis in 
Blood agar, indicating that there was no Hemoglobin oxidation or lysis of red blood cells. These results corroborate the non-pathogenic nature of bacteria constituting bioinoculants (Figure 2) (Ahmad et al. (2013); Zendejas-Manzo et al. (2014); Savardi et al. (2018)).

Moreover, the consortium produced organic acids that allowed to solubilize $\mathrm{P}$ from phosphate rock, as a source of inorganic phosphorous (De Oliveira Mendes et al. (2017); Blanco-Vargas et al. (2020)). In this study, the bacteria that make up the consortium presented similar IS; however, phosphate rock concentrations showed variation in liquid medium, due to the amount of orthophosphate released. This is influenced by the type, structure, molecular weight and the rate of diffusion of the acids produced by the PSB. These features can vary among bacteria; which explains why a correlation was not observed between the IS in solid medium and the concentration of PS in liquid medium (Stella and Halimi (2015); Blanco-Vargas et al. (2020); Mardad et al. (2014)).

Various authors have reported different bacterial genera, e.g. Pseudomonas, Serratia and Enterobacter, as citric-, lactic-, succinic-, gluconic-, oxalic-, glutamic-, and pyruvic-acid producers, among others Krishnaraj and Dahale (2014); Valetti et al. (2018); Aarab et al. (2019); Mardad et al. (2014). The Kosakonia genus has been scarcely reported as a phosphate solubilizer. This genus is tightly related to members of the Enterobacteriaceae family, displaying a high identity among their 16S rDNA sequences (Brady et al. (2013); Kämpfer et al. (2016)). In this study, the results of the taxonomic analysis of Kosakonia sp., isolated from soil where onion is cultivated, based on $16 \mathrm{~S}$ ribosomal gene sequence, revealed $99 \%$ identity with Kosakonia cowanii sequences. Gao et al. (2020) reported Kosakonia cowanii as a promoter of plant growth; they evaluated the exopolysaccharide produced by this bacterium, obtaining positive effects on seed germination and growth vigor of corn plants. Some species of the Kosakonia genus were isolated from environmental sources including soil and plants (Brady et al. (2013)). In addition, bacteria of the Kosakonia genus have the capacity to promote plant growth through nitrogen fixation (Brady et al. (2013)). Berger et al. (2018) reported on Kosakonia pseudosacchari as an endophyte promoter of plant growth in maize. (Cruz-Barrera et al. (2019)) reported Kosakonia radicincitans as a growth promoter with the capacity to solubilize phosphorous with acid and alkaline phosphatase activities. Different PSB have been isolated from rhizosphere of plams (Elaeis guineensis Jacq.) (Acevedo et al. (2014)), chontaduro (B. gassipaes kunth) (Patiño Torres and Sánchez De Prager (2012)), coffee (Coffea arabica) (Cisneros-Rojas et al. (2017)), Cape gooseberry (Physalis peruviana L.) (Becerra et al. (2012)) and onion (Allium cepa) L. (Blanco-Vargas et al. (2020)). Furthermore, bacteria of the genera Alcaligenes, Acinetobacter, Arthrobacter, Azospirillum, Bacillus, Burkholderia, Enterobacter, Erwinia, Flavobacterium, Paenibacillus, Pseudomonas, Rhizobium, and Serratia are recognized for their ability to increase phosphorus availability in soils, where the most potent phosphate solubilizers are of the genus Pseudomonas, Bacillus, and Rhizobium (Krishnaraj and Dahale (2014)).

\subsection{Culture medium design}

For bioinoculant production the most important criterion is microorganism biological activity, since it is the essence of the product. Usually, isolation is carried out from the soil of the crop to which it will be applied (Zambrano-Moreno et al. $(2015 \mathrm{a}, \mathrm{b})$ ). In this study, the criteria to select culture media were fast PSB population growth, with P solubilization from phosphate rock and consortium SP release. 
The Plackett-Burman ANOVA was significant ( $p=0.0101$ ) and the $F$ factor (time) was the most significant $(p=0.0003)$ with a contribution of $83.4 \%$ and a negative standard effect $(-1.77)$ (Table 3). Hereupon, the factor time was determinant to work with production times of $6 \mathrm{~h}$ to favor biomass production and $\mathrm{P}$ release from phosphate rock into culture media.

The PSB consortium grew in the selected conditions for MT11B media. At $12 \mathrm{~h}$ this consortium obtained counts of 8.1 logarithmic units. To favor consortium's growth, bacteria had to consume the carbon, nitrogen, and phosphorus sources present in the designed media. This is in agreement with reports on bacteria of the genera Pseudomonas, Serratia, and Kosakonia capable of employing different sources of carbon and nitrogen (organic and inorganic) and phosphorus (tricalcium phosphate, hydroxyapatite, iron phosphates, aluminum phosphates and phosphate rock) (Bakhshandeh et al. (2015); De Oliveira Mendes et al. (2017); Parastesh et al. (2019)).

Paredes-Mendoza and Espinosa-Victoria (2010) proposed that the concentration of soluble P can increase as a function of time, due to media acidification, principally due to the transformation of high molecular weight compounds, such as carbohydrates, peptides, and lipids into low molecular weight organic acids. The aforementioned, is in agreement with our results; in T11, residual glucose was the lowest of the 11 treatments. Hence, demonstrating that this carbohydrate, as the carbon source, was assimilated. Moreover, organic acids were released as metabolism products, decreasing the medium's $\mathrm{pH}$ to $4.0 \pm 0.2$ and increasing P solubilization. Koch et al. (2012) evaluated the potential to solubilize phosphorus from 10 Pseudomonas species, observing that bacterial viability can notably decrease when the media reaches very acid $\mathrm{pH}$ levels. As shown in Figure 3, at $10 \mathrm{~h}$ of culture $\mathrm{pH}$ reached one of its lowest values $(3.440 \pm 0.006)$, which is detrimental for bacterial viability, since continued media acidification can be interpreted as loss of biomass viability. This was one of the variables that was taken into account to decrease our production time to $6 \mathrm{~h}$. At this point, a $\mathrm{pH}$ of $3.570 \pm 0.010$ was reached and the PSB culture experienced its highest biomass $\left((10.600 \pm 0.078) \log _{10} \mathrm{CFU} \mathrm{mL}^{-1}\right)$.

Moreover, $\mathrm{N}$ from an organic source (brewer's yeast hydrolysate), is directly related to the production of phosphatases. These enzymes are employed by the PSB, making up the consortium, to release of $\mathrm{P}$ organic forms from an inorganic source, such as phosphate rock and $\mathrm{P}$ (PR) as an assimilable source of P. Consequently, it is necessary to have the adequate nutritional sources under determined concentrations to guarantee a formulation that generates the highest biomass production, which in term produces the necessary metabolites for the required objectives (Angulo-Cortés et al. (2012); Chen et al. (2019); Mardad et al. (2014)).

Temperature and agitation were factors that influenced production conditions. Temperature can accelerate the velocity of metabolic reactions until an optimum is reached. In addition, agitation allows for bacteria to have access to insoluble components in the media, such as phosphate rock in suspension. Last, oxygen transfer is generated by agitation that favors aerobic PSB growth (Behera et al. (2017)).

\subsection{Phosphorus solubilization}

Phosphate solubilizing bacteria release non-available $\mathrm{P}$ to available forms, such as $\mathrm{HPO}_{4}{ }^{-2}$ and $\mathrm{H}_{2} \mathrm{PO}_{4}^{-}$through $\mathrm{H}^{+}$excretion, phosphatase biosynthesis, and the production of organic acids. These processes acidify the medium where PSB are being grown; consequently, $\mathrm{pH}$ can decrease from 7.0 \pm 0.2 to $2.0 \pm 0.2$ (Bakhshandeh et al. (2015); De Oliveira Mendes et al. (2017); Joe et al. (2018)). Phosphate solubilization rate depends on the source of $\mathrm{P}$ and the organism to be evaluated (De Oliveira Mendes et al. (2017)). Suleman et al. (2018); Mardad et al. (2013) attribute this acidification to glucose consumption and organic acid production. The most reported organic 
acids are oxalic-, citric-, succinic-, lactic-, and gluconic-acids (Joe et al. (2018)) . Gluconic acid is produced by PSB and is the most frequently reported. Its synthesis is catalyzed by the enzyme glucose dehydrogenase (E.C. 1.1.5.2.), bound to the membrane of Gram-negative bacteria, by direct oxidation of glucose (Yadav et al. (2015); De Oliveira Mendes et al. (2017); Yadav et al. (2017); Tahir et al. (2018)). The increased production of gluconic acid by PSB (Table 6) has an effect on mineral phosphate solubilization (Oteino et al. (2015); Stella and Halimi (2015); Anzuay et al. (2017)). Our results agreed with these reports, as gluconic acid values of $682 \mathrm{mg} \mathrm{L}^{-1}$ were reached at $6 \mathrm{~h}$ (Table 6) with a soluble P concentration of $45.8 \mathrm{mg} \mathrm{L}^{-1}$ (Figure 3) and SP productivity of $(6.900 \pm 1.427) \mathrm{mg} \mathrm{L}^{-1}$ (Table 4).

Organic P mineralization occurs from phosphatase synthesis, catalyzing the hydrolysis of phosphoric ester bonds (Ahemad and Kibret (2014)). Phosphatase solubilizing bacteria produce phosphatases to initiate organic $\mathrm{P}$ mineralization. These enzymes hydrolyze organic $\mathrm{P}$ ester bonds (membrane phospholipids) present in brewer's yeast hydrolysate, which acts as an inducing substrate. Angulo-Cortés et al. (2012) reported at $24 \mathrm{~h}$ of evaluation a productivity of $(0.072 \pm 0.070) \mathrm{UP} \mathrm{h}^{-1}$ for a PSB co-culture. In contrast, in our work we observed higher acid and alkaline phosphatase activities using the same source of organic $\mathrm{P}$ in the growth medium and in one quarter of the time $(6 \mathrm{~h})$. This demonstrates a higher efficiency in the bioinoculant production process of our PSB consortium (Table 4, Table 5).

Interest in phosphatases has increased in the past years given their possible biotechnological applications. Many microorganisms produce phosphatases that can release inorganic $\mathrm{P}$ from organophosphorus organic complexes, and depending on an optimal $\mathrm{pH}$ they can be classified as acid or alkaline (Behera et al. (2017)). In our study, sequential filtrations of the bioinoculant's supernatant were carried out, quantifying acid and alkaline phosphatases in each filtrate and concentrate to determine the approximate molecular weight range of the phosphatases present (Figure 5). In our experience, about less than half of alkaline phosphatase activity was lost when filtering through $100000 \mathrm{Da}$, implying that their molecular weight surpassed $100000 \mathrm{Da}$. The remaining alkaline phosphatase activity was enriched after filtering through $10000 \mathrm{Da}$ mesh, suggesting that their molecular weight was approximately equal or less than $10000 \mathrm{Da}$. Acid phosphatase activity was concentrated after filtering through $10000 \mathrm{Da}$.

Preobrazhenskaya et al. (2003) have reported phosphatases in Serratia sp., with a molecular weight of $29000 \mathrm{Da}$, whereas Liu et al. (2016); Pramanik et al. (2018a,b); Bheri and Pandey (2019) reported phosphatases in Pseudomonas spp. with a molecular weight of about $50000 \mathrm{Da}$, these molecule sizes are in agreement with our findings. Liu et al. (2016) reported cytoplasmatic, periplasmatic and extracellular alkaline phosphatases in Pseudomonas with a molecular weight lower than $25000 \mathrm{Da}$. Behera et al. (2017) reported a partially pure alkaline phosphatase from Alcaligenes faecalis, isolated from mangrove soils with three bands of approximately $45000 \mathrm{Da}, 25000 \mathrm{Da}$, and $17000 \mathrm{Da}$. Collectively, reports and results demonstrate molecular weight variation for these enzymes. The phosphatases present in the bioinoculant are valuable constituent of the product, since they provided and additional solubilization mechanism by organic acid production, which made $\mathrm{P}$ readily available for plant use.

Alori et al. (2017) defined in their research the "sink theory" that supports the process of organic $\mathrm{P}$ solubilization, addressing continuous $\mathrm{P}$ elimination as a result of dissolution of elements associated to P. Phosphate degradation in organic substrates is constantly correlated to biomass' $\mathrm{P}$ content. Phosphatases are involved in this process; they catalyze the dephosphorylation of ester bonds in organic compounds. Behera et al. (2017) studied P solubilization and acid phosphatase activity in Serratia sp., describing phosphatase activity closely associated with, and influenced by, 
growth parameters such as $\mathrm{pH}$, temperature, agitation velocity, sources of carbon, and nitrogen. Therefore, to optimize phosphatase production within the consortium, it would be necessary to evaluate the previously mentioned parameters through an experimental design.

\subsection{Biomass stability at different temperatures and $\mathbf{p H}$}

Phosphate solubilizing bacteria competitiveness in natural environments depends on their capacity to survive and replicate in the soil, which is influenced by environmental factors, such as soil composition, temperature, $\mathrm{pH}$, soil texture, humidity, and substrate availability (Khan et al. (2007)). Our bioinoculant stability depended on various factors, two of the most important were temperature and $\mathrm{pH}$. As to the former, bioinoculant biomass experienced its maximum stability $(80 \%)$ at temperatures between $(8 \pm 2){ }^{\circ} \mathrm{C}$ and $(30 \pm 2){ }^{\circ} \mathrm{C}$ (Figure 4a). Furthermore, for P release, $(30 \pm 2)^{\circ} \mathrm{C}$ was remarkable; at this temperature the highest concentration of $(51.6 \pm 1.2) \mathrm{mg} \mathrm{L}^{-1}$ was attained (Figure $\left.4 \mathrm{~b}\right)$. Hence, $30^{\circ} \mathrm{C}$ was selected as the most adequate temperature to maintain the bioinoculant's stability in terms of biomass and soluble P release into the media. These results are in agreement with those of Suleman et al. (2018), who also evaluated the effect of temperature and $\mathrm{pH}$ on P solubilization by Pseudomonas sp., MS16 and Enterobacter sp., MS32 obtaining similar results $\left(22.5^{\circ} \mathrm{C}\right.$ and $\mathrm{pH} 7.0 \pm 0.2$ ) (Suleman et al. (2018)). (Aliasgharzad et al., 2009) reported optimal temperatures of $27^{\circ} \mathrm{C}$ during the day and $18^{\circ} \mathrm{C}$ at night in onion fields. Álvarez-Hernández et al. (2011) reported environmental temperate and cold climates at 900 masl, with environmental average temperatures of $25^{\circ} \mathrm{C}$, during the fall. Ikeda et al. (2019) compared different temperatures in an onion field where the best results were obtained at $25^{\circ} \mathrm{C}$. The previously mentioned reports relate to the temperature stability obtained in our study, since the highest viability percentage was obtained at $(30 \pm 2)^{\circ} \mathrm{C}(100 \%)$, suggesting that the bioinoculant could be used in the field at temperatures close to this one.

At $40{ }^{\circ} \mathrm{C}$ and $50{ }^{\circ} \mathrm{C} \mathrm{PSB}$ viability decreased ( $48 \%$ and $25 \%$, respectively), which could be due to changes in bacterial cell membranes, involving protein denaturalization, membrane lipid fusion, and cell wall lysis (Figure 4a). Huguet et al. (2019) explained the mechanisms bacteria use to withstand high temperatures. Their proposed that bacteria adaptability to high temperatures is achieved through a high content of long chain saturated lipids forming hydrophobic bonds, stable at high temperatures. This accounts for the observed loss of cell viability for the PSB at temperatures of $40^{\circ} \mathrm{C}$ and $50^{\circ} \mathrm{C}$, since the consortium were mesophylls that don't have the characteristics required to withstand high temperatures.

As for the relation between biomass stability and $\mathrm{pH}$, the bioinoculant was more sensitive to changes in $\mathrm{pH}$. Bioinoculant biomass decreased in all evaluated $\mathrm{pH}$ ranges (Figure $4 \mathrm{c}$ ). At $12 \mathrm{~h}$ of biomass evaluation the least viability loss was observed at $\mathrm{pH} 6.0 \pm 0.2$, revealing $68 \%$ stability with $(7.200 \pm 0.009) \log _{10} \mathrm{CFU} \mathrm{mL} \mathrm{mL}^{-1}$ count in comparison to $100 \%$ stability at the beginning $\left((10.50 \pm 0.14) \log _{10} \mathrm{CFU} \mathrm{mL}^{-1}\right)$, (Figure 4). Our results are in agreement by those obtained by Patel et al. (2016), who determined bacterial tolerance to changes in $\mathrm{pH}$ is limited. Furthermore, harsh changes can result in viability loss. Since $\mathrm{pH}$ affects the microorganism's cytoplasmic membrane, solute transport, enzyme inhibition, and protein denaturation (Patel et al. (2016)).

De Oliveira Mendes et al. (2017) described in their study how culture media pH directly influences the microorganism's growth and the biochemical processes that take place. This, coupled with the fact that acidification is the main mechanism involved in $\mathrm{P}$ solubilization, support the importance of studying the medium's $\mathrm{pH}$ effect on the capacity the microorganisms have to solubilize; Marra et al. (2015) studied such capacity in 82 strains, finding a correlation between medium $\mathrm{pH}$ and the amount of solubilized P. They concluded that PSB presented an optimal growth at a $\mathrm{pH}$ 
range between $5.0 \pm 0.2$ and $7.0 \pm 0.2$. In our study, we demonstrated that the highest soluble $P$ concentrations of $(45.6 \pm 1.7) \mathrm{mg} \mathrm{L}^{-1}$ and $(47.60 \pm 2.24) \mathrm{mg} \mathrm{L}^{-1}$ were obtained at a $\mathrm{pH}$ between $6.0 \pm 0.2$ and $7.0 \pm 0.2$ (Figure $4 \mathrm{~d}$ ). Jha et al. studied the effect of $\mathrm{pH}$ and temperature on $\mathrm{P}$ solubilization employing PSB of the genera Burkholderia, Enterobacter, Serratia, Klebsiella, and Aeromonas. They revealed that the optimal temperature for $\mathrm{P}$ solubilization from di-calcium phosphate, tri-calcium phosphate, and phosphate rock was $35^{\circ} \mathrm{C}$ a pH $6.0 \pm 0.2$; this is supported by our observations (Figure 4a).

$\mathrm{pH}$ is an important factor for adsorption and microorganism elaboration of biofilms to different types of supports, since it can increase or decrease the number of cells adsorbed. Zhao et al. (2018) highlighted that at pH 7 bacteria generally present a net negative charge on their cell wall. The physical properties of the support's surface, including its composition and roughness, influence biofilm formation. In addition, environmental factors such as, $\mathrm{pH}$ and temperature similarly play a role. Last, the microbial species, nutrient availability, cell mobility, temperature, and hydrophobicity also have an effect. In our study, we evidenced PSB biofilm formation on the surface of phosphate rock, present in MT11B medium (Figure 6). Rabin et al. (2015) reported biofilm formation by Pseudomonas aeruginosa and bacteria of the Enterobacteriaceae family, by means of exopolysaccharide (EPS) production that served to support bacteria to the surface. They pointed out that certain EPS are not specific of biofilms, but their production increases as a result of response to stress, such as acid production. In contrast, Bales et al. (2013) noted that EPS can be a main constituent associated with biofilm development.

\subsection{Bioinoculant and organic mineral fertilizer effects on onion growth}

According to Blanco-Vargas et al. (2020), the soil of the sowing plot is acidic (pH 4.7) with high content of available $\mathrm{P}\left(250 \mathrm{mg} \mathrm{kg}^{-1}\right)$, intermediate aluminum content $\left(17 \mathrm{mg} \mathrm{kg}^{-1}\right)$ and iron (42 $\mathrm{mg} \mathrm{kg}^{-1}$ ), and low organic matter $(6.87 \%)$. Moreover, the soil's PSB populations reached values of $5 \times 10^{3} \mathrm{CFU} \mathrm{g}^{-1}$.

Some factors that can affect bacterial behavior in soil are nutrient content, soil type, and plant species present (Valetti et al. (2018)). Diverse bacterial genera are capable of solubilizing phosphorus and are known to promote the growth of crops, such as garlic, Allium sativum L. (Damse et al. (2014)); rapeseed, Brassica napus (Valetti et al. (2018)); African oil palm, Elaeis guineensis Jacq. (Acevedo et al. (2014)); rice, Oryza sativa L. (Bakhshandeh et al. (2015); Rasul et al. (2019)); and wheat Triticum aestivum (Mukhtar et al. (2017); Cherchali et al. (2019); Anzuay et al. (2017)) studied the effect of simple and mixed inoculants made of six PSB on crop growth; the PSB Pantoea sp. J49, Bacillus sp. L55, Serratia sp. S119, Acinetobacter sp., L176, Enterococcus sp., L191 and Serratia sp., J260 were evaluated on native peanut, Arachis hypogaea L., and maize, Zea mays L., growth. The authors observed an increase in seed germination, plant growth, and P content. The employed PSB were capable of solubilizing and mineralizing phosphorus, thus making them potential biofertilizers for these crops (Anzuay et al. (2017)). (Ahemad and Kibret, 2014) reported PSB use isolated from soils from different crops to possibly improve plant growth. In a study performed by Blanco-Vargas et al. (2020) with Pseudomonas sp. and Serratia sp., the effect of these PSB was evaluated on onion growth. When the bacterial co-culture was applied at $8.0 \log _{10} \mathrm{CFU} \mathrm{mL} \mathrm{m}^{-1}$ twice a week for two months, an increase in total onion dry weight and seedling growth was observed. Authors attributed these results to organic acids produced by the evaluated PSB, which augmented P release into the soil where onion was grown. 
Onion culture is characterized for its high nitrogen, phosphorus, potassium, and calcium concentration requirements (Mohamed et al. (2014); Tekeste et al. (2018)). In the field plots herein evaluated, extractable $\mathrm{P}$ concentration was high $\left(250 \mathrm{mg} \mathrm{kg}^{-1}\right)$; however, the presence of iron and aluminum diminished their availability. Doses of $200 \mathrm{~kg} \mathrm{ha}^{-1}$ can generate an excess in the soil with the consequent precipitation of other nutrients. Frequently, an excess of P content in the soil and high doses do not represent a benefit or may even adversely affect the productivity of onion crops. In our study, onions grown with the highest doses of the organic mineral fertilizer, Abundagro ${ }^{\circledR}$, did not attain the highest growth, not even when received the PSB inoculant simultaneously.

The plants that did not receive fertilizer grew the least and revealed the lowest bulb P content. A similar scenario was observed for onions treated with the lowest doses of organic mineral fertilizer. Although the concentration of extractable $\mathrm{P}$ in the soil before sowing exceeded the optimal range for the production of bulbs, $129 \mathrm{mg} \mathrm{kg}^{-1}$ to $168 \mathrm{mg} \mathrm{kg}^{-1}$, its low availability affected the growth of plants in the treatments without PSB. In contrast, the application of the bioinoculant favored the outcomes of the plant variables evaluated in the trial, including those of plants exposed to the bioinoculant only (T13) (Table 7).

When comparing T4 $\left(100 \mathrm{~kg} \mathrm{ha}^{-1}\right.$ of Abundagro ${ }^{\circledR}$ plus $500 \mathrm{~mL}$ PSB) with T10 $\left(100 \mathrm{~kg} \mathrm{ha}^{-1}\right.$ Abundagro ${ }^{\circledR}$ ) and T13 (1000 mL PSB), we observed higher values of total phosphorus in T10 bulbs but lesser plant growth. This could be related to the organic and mineral characteristics of the fertilizer and to the action of the soil's own PSB, which were able to solubilize part of the total phosphorus present in fertilizer (initial soil PSB counts $5 \times 10^{3} \mathrm{CFU} \mathrm{mL}^{-1}$ ) (Table 7).

The onions grown in the presence of $1000 \mathrm{~mL}$ PSB only (T13) had a lower phosphorus bulb content; however, their plant growth variables surpassed those of T10 onions. The results of treatments T4 and T13, suggest that the bacteria making up the inoculant not only solubilized phosphorous, but also could have other biological activities related to plant growth promotion that were not assessed by our work. Therefore, onion growers could apply $100 \mathrm{~kg} \mathrm{ha}^{-1}$ Abundagro $^{\circledR}$ plus $500 \mathrm{~mL}$ PSB in a concentration of $10 \times 10^{7} \mathrm{CFU} \mathrm{mL}^{-1}$ to their crops thereby reducing the recommended dose of Abundagro ${ }^{\circledR}$ by $50 \%$, reaching a more economic and sustainable alternative with the environment (Table 7).

Microbial phosphate solubilization from phosphate rock is a high-efficiency process, according to reports by various authors; PSB have short growth times, which allows for high yields in short time lapses (Jha et al.; Ahmad et al. (2013); Oteino et al. (2015); Zambrano-Moreno et al. (2015a); Ludueña et al. (2017); Suleman et al. (2018)). Results from our work demonstrate that the bacterial consortium conformed by Pseudomonas sp., Serratia sp., and Kosakonia sp. produces diverse organic acids and phosphatases that increase soluble $\mathrm{P}$ concentration, thus promoting onion growth. One characteristic that favored the process was its production from an inorganic P source, the same used in plot assays.

High phosphorus concentrations can induce swifter organic acid production (Maghraoui et al. (2016)). Likewise, according to (Serna Posso et al., 2017) phosphate release depended on the source of $\mathrm{P}$, as well as on the organic acid produced and its concentrations. $\mathrm{P}$ solubilization from $\mathrm{P}-\mathrm{Ca}^{2+}$ was greater in comparison with $\mathrm{P}-\mathrm{Al}^{3+}$, which in term was greater than $\mathrm{P}-\mathrm{Fe}^{3+}$. Our bioinoculant's capacity to produce in vitro gluconic-, citric-, and oxalic-acids, which lead to $\mathrm{P}$ release from phosphate rock with approximately $24 \%$ calcium and $1 \%$ aluminum, allowed to increase the element's availability within the bioinoculant and in the soil where onion was cultured and fertilized with this product. 
In general, the mix of fertilizer and bioinoculant resulted in better onion growth. Similar results were reported by Yoldas et al. (2011) who evaluated the effect of organic and inorganic fertilizers on the growth and mineral content of onion. Yadav et al. (2017) applied $75 \%$ organic compost and $25 \%$ PSB and phosphate rock to a wheat crop, demonstrating a maximal soluble P concentration in comparison with plants fertilized with compost without PSB and phosphate rock (Behera et al. (2017); Yadav et al. (2017)). Moreno-Bayona et al. (2019) evaluated the effect of fertilizing soil where onion is grown with a consortium of PSB conformed by Pseudomonas sp, Kosakonia sp. and Serratia sp. immobilized in biochar, observing the positive effect of the consortium on onion growth after five weeks.

\section{Conclusions}

Phosphate rock can be used as an inorganic source of P for PSB, when incorporated in culture media for biofertilizer production and its subsequent direct application to soils in the field. The co-application of a bioinoculant consisting of a consortium of PSB, produced in MT11B medium, and a commercial biofertilizer, like Abundagro ${ }^{\circledR}$, improved onion growth, the content of $\mathrm{P}$ in the bulb, and the former's availability in soil.

\section{Acknowledgements}

This work was financed by The Government of Boyacá, and the Departamento Administrativo de Ciencia y Tecnología e Innovación y COLCIENCIAS, Grant No. 733 of 2015: "Formación de capital humano de alto nivel para el departamento de Boyacá" and by "Pontificia Universidad Javeriana Bogotá, D.C. Colombia" Grant ID 8626 with the project titled Development of a biofertilizer from biochar and phosphate solubilizing bacteria for culture of Allium cepa $L$. "Desarrollo de un biofertilizante a base de biochar y bacterias fosfato solubilizadoras para el cultivo de Allium cepa L.". Grant ID 00007681 with the project titled Combined use of ligninolytic fungi and pyrolysis to obtain a modified biochar using a biodefinery model. "Uso combinado de hongos ligninolíticos y pirolisis para la obtención de un biochar modificado empleando un modelo de biodefinería". Authors thank agronomist Gabriel Arguello for contacting farmers, donating the Abundagro ${ }^{\circledR}$ organic fertilzer to conduct field experiments, and providing assistance throughout the execution of this project. To Dr. Cesar López and Mr. Paulino Pérez, for allowing soil sampling in Boyacá. To Mr. Ferney Viancha, for donating onion (Allium cepa L.) seeds and allowing experimental plot use. To Mr. Alejandro Pedroza and Mr. Carlos Pedroza, for their availability and field work assistance. To Dr. Ana Karina Carrascal, for technical support with pathogenesis assays. To Dr. Rodrigo Ortega Blu for implementing the geostatistical techniques used in soil sampling and to Dr. María Lucía Gutiérrez, for English editing.

\section{Competing interests}

The authors declare that no competing interests exist. 


\section{References}

Aarab S, Ollero J, Megías M, Laglaoui A, Bakkali M \& Arakrak A. Some characteristics of phosphate solubilizing rhizobacteria as an ecological strategy for sustainable agriculture, Materials Today: Proceedings, 13 (3): 1224-1228, 2019.

http://doi.org/10.1016/j.matpr.2019.04.091

Acevedo E, Galindo-Castañeda T, Prada F, Navia M \& Romero HM. Phosphate-solubilizing microorganisms associated with the rhizosphere of oil palm (Elaeis guineensis Jacq.) in Colombia, Applied Soil Ecology, 80: 26-33, 2014.

http://doi.org/10.1016/j.apsoil.2014.03.011

Ahemad M \& Kibret M. Mechanisms and applications of plant growth promoting rhizobacteria: Current perspective, Journal of King Saud University - Science, 26 (1): 1-20, 2014. http://doi.org/10.1016/j.jksus.2013.05.001

Ahmad E, Khan MS \& Zaidi A. ACC deaminase producing Pseudomonas putida strain PSE3 and Rhizobium leguminosarum strain RP2 in synergism improves growth, nodulation and yield of pea grown in alluvial soils, Symbiosis, 61: 93-104, 2013. http://dx.doi.org/10.1007/s13199-013-0259-6

Ahmad E, Zaidi A \& Khan MS. Response of PSM Inoculation to Certain Legumes and Cereal Crops, in Khan, Zaidi \&Musarrat, (Eds). Phosphate Solubilizing Microorganisms. Springer, Cham, 2014, p. 175-205.

Aliasgharzad N, Bolandnazar SA, Neyshabouri MR \& Chaparzadeh N. Impact of soil sterilization and irrigation intervals on $\mathrm{P}$ and $\mathrm{K}$ acquisition by mycorrhizal onion (Allium cepa), Biologia, 64 (3): 512-515, 2009.

http://doi.org/10.2478/s11756-009-0072-0

Alori ET, Glick BR \& Babalola OO. Microbial phosphorus solubilization and its potential for use in sustainable agriculture, Frontiers in Microbiology, 8: 971, 2017.

http://doi.org/10.3389/fmicb.2017.00971

Álvarez-Hernández JC, Venegas-Flores S, Soto-Ayala C, Chávez-Vargas A \& Zavala-Sánchez L. Uso de fertilizantes químicos y orgánicos en cebolla (Allium cepa L.) en Apatzingán, Michoacán, México, Avances en Investigación Agropecuaria, 15 (2): 29-43, 2011.

Angulo-Cortés JP, García-Díaz A, Pedroza AM, Martínez-Salgado MM \& Gutiérrez-Romero V. Diseño de un medio para la producción de un co-cultivo de bacterias fosfato solubilizadoras con actividad fosfatasa, Universitas Scientiarum, 17 (1): 43-52, 2012.

Anzuay MS, Ruiz Ciancio MG, Ludueña LM, Angelini JG, Barros G, Pastor N \& Taurian T. Growth promotion of peanut (Arachis hypogaea L.) and maize (Zea mays L.) plants by single and mixed cultures of efficient phosphate solubilizing bacteria that are tolerant to abiotic stress and pesticides, Microbiological Research, 199: 98-109, 2017.

http://doi.org/10.1016/j.micres.2017.03.006

Bakhshandeh E, Rahimian H, Pirdashti H \& Nematzadeh GA. Evaluation of phosphatesolubilizing bacteria on the growth and grain yield of rice (Oryza sativa L.) cropped in Northern Iran Journal of Applied Microbiology, 119 (5): 1371-1382, 2015.

http://doi.org/10.1111/jam.12938 
Bales PM, Renke EM, May SL, Shen Y \& Nelson DC. Purification and Characterization of Biofilm-Associated EPS Exopolysaccharides from ESKAPE Organisms and Other Pathogens, Plos One, 8 (6): e67950, 2013.

http://dx.doi.org/10.1371/journal.pone.0067950

Becerra JM, Quintero D, Martínez M \& Matiz A. Caracterización de microorganismos solubilizadores de fosfato aislados de suelos destinados al cultivo de uchuva (Physalis peruviana $\mathrm{L}$.) Revista Colombiana de Ciencias Hortícolas, 5 (2): 186-194, 2011. http://doi.org/10.17584/rcch.2011v5i2.1265

Behera B, Singdevsachan S, Mishra R, Dutta S \& Thatoi H. Diversity, mechanism and biotechnology of phosphate solubilising microorganism in mangrove-A review, Biocatalysis and Agricultural Biotechnology, 3 (2): 97-110, 2014.

http://doi.org/10.1016/j.bcab.2013.09.008

Behera BC, Yadav H, Singh SK, Mishra RR, Sethi BK, Dutta SK \& Thatoi HN. Phosphate solubilization and acid phosphatase activity of Serratia sp. isolated from mangrove soil of Mahanadi river delta, Odisha, India, Journal of Genetic Engineering and Biotechnology, 15: 169-178, 2017.

http://dx.doi.org/10.1016/j.jgeb.2017.01.003

Beheshti M, Etesami H \& Alikhani HA. Interaction study of biochar with phosphate-solubilizing bacterium on phosphorus availability in calcareous soil, Archives of Agronomy and Soil Science, 60 (11): 1572-1581, 2017. http://doi.org/10.1080/03650340.2017.1295138

Berger B, Patz S, Ruppel S, Dietel K, Faetke S, Junge H \& Becker M. Successful formulation and application of plant growth-promoting Kosakonia radicincitans in maize cultivation, BioMed Research International, 2018: Article ID 6439481, 2018. http://doi.org/10.1155/2018/6439481

Bheri M \& Pandey GK. Protein phosphatases meet reactive oxygen species in plant signaling networks, Environmental and Experimental Botany, 161: 26-40, 2019. http://doi.org/10.1016/j.envexpbot.2018.10.032

Blanco C \& Lagos J, Manual de producción de cebolla, ed., Instituto de Investigaciones Agropecuarias (INIA), Santiago de Chile, Chile 2017, 104 pp.

Blanco-Vargas A, Rodríguez-Gacha LM, Sánchez-Castro N, Garzón-Jaramillo R, PedrozaCamacho LD, Poutou-Piñales RA, Rivera-Hoyos CM, Díaz-Ariza LA \& Pedroza-Rodríguez AM. Phosphate-solubilizing Pseudomonas sp. and Serratia sp., co-culture for Allium cepa L. growth promotion, Heliyon 6 (10): e05218, 2020.

http://doi.org/10.1016/j.heliyon.2020.e05218

Boyhan GE, Torrance RL \& Hill CR. Effects of nitrogen, phosphorus, and potassium rates and fertilizer sources on yield and leaf nutrient status of short-day onions, HortSience, 42 (3): 653-660, 2007.

http://doi.org/10.21273/HORTSCI.42.3.653

Brady C, Cleenwerck I, Venter S, Coutinho T \& De Vos P. Taxonomic evaluation of the genus Enterobacter based on multilocus sequence analysis (MLSA): Proposal to reclassify E. nimipressuralis and E. amnigenus into Lelliottia gen. nov. as Lelliottia nimipressuralis 
comb. nov. and Lelliottia amnigena comb. nov., respectively, E. gergoviae and E. pyrinus into Pluralibacter gen. nov. as Pluralibacter gergoviae comb. nov. and Pluralibacter pyrinus comb. nov., respectively, E. cowanii, E. radicincitans, E. oryzae and E. arachidis into Kosakonia gen. nov. as Kosakonia cowanii comb. nov., Kosakonia radicincitans comb. nov., Kosakonia oryzae comb. nov. and Kosakonia arachidis comb. nov., respectively, and E. turicensis, E. helveticus and E. pulveris into Cronobacter as Cronobacter zurichensis nom. nov., Cronobacter helveticus comb. nov. and Cronobacter pulveris comb. nov., respectively, and emended description of the genera Enterobacter and Cronobacter, Systematic and Applied Microbiology, 36 (5): 309-319, 2013.

http://doi.org/10.1016/j.syapm.2013.03.005

Bushra T, Anwar K, Muhammad T, Memoona R, Muhammad Saleem IK, Naila S \& Khadija A. Bottlenecks in commercialisation and future prospects of PGPR, Applied Soil Ecology, 121: 102-117, 2017.

http://doi.org/10.1016/j.apsoil.2017.09.030

Chen M, Cheng J, Zhang J, Chen Y, Zeng H, Xue L, Lei T, Pang R, Wu S, Wu H, Zhang S, Wei X, Zhang Y, Ding Y \& Wu Q. Isolation, Potential Virulence, and Population Diversity of Listeria monocytogenes From Meat and Meat Products in China, Frontiers in Microbiology, 10: Article 946, 2019.

http://doi.org/10.3389/fmicb.2019.00946

Cherchali A, Boukhelata N, Kaci Y, Abrous-Belbachir O \& Djebbar R. Isolation and identification of a phosphate-solubilizing Paenibacillus polymyxa strain GOL 0202 from durum wheat (Triticum durum Desf.) rhizosphere and its effect on some seedlings morphophysiological parameters, Biocatalysis and Agricultural Biotechnology, 19: 101087, 2019. http://doi.org/10.1016/j.bcab.2019.101087

Cisneros Rojas CA, Sánchez de P. M \& Menjivar F. JC. Identificación de bacterias solubilizadoras de fosfatos en un andisol de la región cafetera colombiana, Revista Colombiana de Biotecnología, XIX (1): 21-28, 2017.

http://dx.doi.org/10.15446/rev.colomb.biote.v19n1.65966

Collins CH \& Lyne PM, Collins and Lyne's Microbiological Methods, 8 Ed. ed., Taylor \& Francis Ltd, London, United Kingdom 2004, 480p.

Cruz-Barrera M, Jakobs-Schoenwandt D, Gómez MI, Becker M, Patel AV \& Ruppel S. Salt stress and hydroxyectoine enhance phosphate solubilisation and plant colonisation capacity of Kosakonia radicincitans, Journal of Advanced Research, 19: 91-97, 2019. http://doi.org/10.1016/j.jare.2019.03.012

Damse D, Bhalekar MN \& Pawar PK. Effect of integrated nutrient management on growth and yield of garlic, The Bioscan, 9 (4): 1557-1560, 2014.

De Oliveira Mendes G, Galvez A, Vassileva M \& Vassilev N. Fermentation liquid containing microbially solubilized P significantly improved plant growth and P uptake in both soil and soilless experiments, Applied Soil Ecology, 117-118: 208-211, 2017. http://dx.doi.org/10.1016/j.apsoil.2017.05.008

De Oliveira Mendes G, Lopez Zafra D, Vassilev NB, Ribeiro Silva I, Ribeiro JI \& Dutra Costa M. Biochar Enhances Aspergillus niger Rock Phosphate Solubilization by Increasing Organic Acid Production and Alleviating Fluoride Toxicity, Applied and Envinronmental Microbiology, 80 (10): 3081-3085, 2014. 
http://doi.org/10.1128/AEM.00241-14

Doran PM, Bioprocess Engineering Principles, ed., Elsevier Ltd. 2013

Gao H, Lu C, Wanga H, Wang L, Yang Y, Jiang T, Li S, Xu D \& Wu L. Production exopolysaccharide from Kosakonia cowanii LT-1 through solid-state fermentation and its application as a plant growth promoter, International Journal of Biological Macromolecules, 150: 955-964, 2020. http://doi.org/10.1016/j.ijbiomac.2019.10.209

Grageda-Cabrera OA, Díaz-Franco A, Peña-Cabriales JJ \& Vera-Nuñez JA. Impact of biofertilizers in agriculture, Revista Mexicana de Ciencias Agrícolas, 3 (6): 1261-1274, 2012.

Hach Company/Hach Lange GmbH (2007) HACH 8507: Nitrogen nitrite--low range, diazotization method for water and wastewater. pp: 4.

Hernández-Sáenz D, Puentes-Morales CS, Mateus-Maldonado JF, Pedroza-Camacho LD, RamírezRodríguez J, Rivera-Hoyos CM \& Pedroza-Rodríguez AM. Evaluación del consorcio entre Pleurotus ostreatus, Trametes versicolor y bacterias aeróbicas para remoción de colorantes sintéticos, Revista Colombiana de Biotecnología, 12: 45-59, 2020.

http://dx.doi.org/10.15446/rev.colomb.biote.v22n1.82735

Huguet A, Coffinet S, Roussel A, Gayraud F, Anquetil C, Bergonzini L, Bonanomi G, Williamson $\mathrm{D}$, Majule A \& Derenne S. Evaluation of 3-hydroxy fatty acids as a $\mathrm{pH}$ and temperature proxy in soils from temperate and tropical altitudinal gradients, Organic Geochemistry, 129: 1-13, 2019.

http://doi.org/10.1016/j.orggeochem.2019.01.002

ICONTEC (2011a) Bioinsumos para uso agrícola. Inoculantes biológicos. NTC 5842. pp: 13.

ICONTEC (2011b) Norma Técnica Colombiana 5167 (segunda actualización). Productos para la industria agrícola. Productos orgánicos usados como abonos o fertilizantes y enmiendas de suelo. pp: 10.

Ikeda H, Kinoshita T, Yamamoto T \& Yamasaki A. Sowing time and temperature influence bulb development in spring-sown onion (Allium cepa L.), Scientia Horticulturae, 244: 242-248, 2019.

http://doi.org/10.1016/j.scienta.2018.09.050

Jayathilake PKS, Reddy IP, Srihari D \& Reddy KR. Productivity and soil fertility status as influenced by integrated use of $\mathrm{N}$-fixing biofertilizers, organic matures and inorganic fertilizers in onion The Journal of Agricultural Sciences, 2 (1): 46-58, 2006.

Jha A, Saxena J \& Sharma V. Investigation on phosphate solubilization potential of agricultural soil bacteria as affected by different phosphorus sources, temperature, salt, and pH, Communications in Soil Science and Plant Analysis 44 (16): 2443-2458, 2013.

http://doi.org/10.1080/00103624.2013.803557

Joe MM, Deivaraj S, Benson A, Henry AJ \& Narendrakumar G. Soil extract calcium phosphate media for screening of phosphate-solubilizing bacteria, Agriculture and Natural Resources, 52 (3): 305-308, 2018. http://doi.org/10.1016/j.anres.2018.09.014 
Kämpfer P, McInroy JA, Doijad S, Chakraborty T \& Glaeser SP. Kosakonia pseudosacchari sp. nov., an endophyte of Zea mays, Systematic and Applied Microbiology, 39 (1): 1-7, 2016. http://doi.org/10.1016/j.syapm.2015.09.004

Khan MS, Zaidi A \& Wani PA. Role of phosphate-solubilizing microorganisms in sustainable agriculture-A review, Agronomy for Sustainable Development, 27 (1): 29-43, 2007. http://doi.org/10.1051/agro:2006011

Koch S, Majewski E, Schmeisky H \& Schmidt FRJ. Critical evaluation of phosphate solubilizing Pseudomonads isolated from a partially recultivated potash tailings pile, Current Microbiology, 65 (2): 202-206, 2012. http://doi.org/10.1007/s00284-012-0145-0

Krishnaraj PU \& Dahale S. Mineral phosphate solubilization: Concepts and prospects in sustainable agriculture, Proccedings Indian National Science Academy, 80 (2): 389-405, 2014. http://doi.org/10.16943/ptinsa/2014/v80i2/55116

Liu X, Long D, You H, Yang D, Zhou S, Zhang S, Li M, He M, Xiong M \& Wang X. Phosphatidylcholine affects the secretion of the alkaline phosphatasePhoA in Pseudomonas strains, Microbiological Research, 192: 21-29, 2016.

http://dx.doi.org/10.1016/j.micres.2016.02.001

Lobo CB, Juárez Tomása MS, Viruel E, Ferrero MA \& Lucca ME. Development of lowcost formulations of plant growth-promoting bacteria to be used as inoculants in beneficial agricultural technologies, Microbiological Research, 219: 12-25, 2019.

http://doi.org/10.1016/j.micres.2018.10.012

Ludueña M, Anzuay M, Magallanes C, Tonelli ML, Ibañez F, Angelini J \& Taurian T. Effects of P limitation and molecules from peanut root exudates on $p q q \mathrm{E}$ gene expression and pqq promoter activity in the phosphate-solubilizing strain Serratia sp. S119, Research in Microbiology, 168 (8): 710-721, 2017. http://doi.org/10.1016/j.resmic.2017.07.001

Maghraoui T, Bechtaoui N, Galiana A, Wahbi S, Duponnois R, Hafidi M, Daoui A, Zain eAF, De Lajudie P \& Oufdou K. Effect of inoculation by Moroccan rock phosphate solubilizing rhizobia, versus phosphorus fertilization, on the growth and the phosphorus uptake by Vicia faba, Pakistan Journal of Agricultural Sciences, 53 (4): 817-826, 2016. http://doi.org/10.21162/PAKJAS/16.3461

Mardad I, Serrano A \& Soukri A. Effect of carbon, nitrogen sources and abiotic stress on phosphate solubilization by bacterial strains isolated from a moroccan rock phosphate deposit, Journal of Advanced Chemical Engineering, 4 (1): 1000102, 2014. http://doi.org/10.4172/2090-4568.1000102

Mardad I, Serrano A \& Soukri AA. Solubilization of inorganic phosphate and production of organic acids by bacteria isolated from a Moroccan mineral phosphate deposit, African Journal of Microbiology Research, 7 (8): 626-635, 2013. http://doi.org/10.5897/AJMR12.1431

Marra LM, de Oliveira-Longatti SM, Soares CRFS, de Lima JM, Olivares FL \& Moreira FMS. Initial $\mathrm{pH}$ of medium affects organic acids production but do not affect phosphate solubilization, Brazilian Journal of Microbiology, 46 (2): 367-375, 2015. http://doi.org/10.1590/S1517-838246246220131102 
Miller G. Use of dinitrosalicylic acid reagent for determination of reducing sugar, Analytical Chemistry, 31 (3): 426-428, 1959.

http://dx.doi.org/10.1021/ac60147a030

Mohamed AA, Eweda WEE, Heggo AM \& Hassan EA. Effect of dual inoculation with arbuscular mycorrhizal fungi and sulphur-oxidising bacteria on onion (Allium cepa L.) and maize (Zea mays L.) grown in sandy soil under green house conditions, Annals of Agricultural Science, 59 (1): 109-118, 2014. http://dx.doi.org/10.1016/j.aoas.2014.06.015

Moreno-Bayona DA, Gómez-Méndez LD, Blanco-Vargas A, Castillo-Toro A, Herrera-Carlosama L, Poutou-Piñales RA, Salcedo-Reyes JC, Díaz-Ariza LA, Castillo-Carvajal LC, Rojas-Higuera NS \& Pedroza-Rodríguez AM. Simultaneous bioconversion of lignocellulosic residues and oxodegradable polyethylene by Pleurotus ostreatus for biochar production, enriched with phosphate solubilizing bacteria for agricultural use, Plos One, 14 (5): e0217100, 2019. http://doi.org/10.1371/journal.pone.0217100

Mukhtar S, Shahid I, Mehnaz S \& Malik KA. Assessment of two carrier materials for phosphate solubilizing biofertilizers and their effect on growth of wheat (Triticum aestivum L.), Microbiological Research, 205: 107-117, 2017.

http://dx.doi.org/10.1016/j.micres.2017.08.011

Munda S, Shivakumara BG, Rana DS, Gangaiah B, Manjaiah KM, Dass A, Layek J \& Lakshman K. Inorganic phosphorus along with biofertilizers improves profitability and sustainability in soybean (Glycine max)-potato (Solanum tuberosum) cropping system, Journal of the Saudi Society of Agricultural Sciences, 17 (2): 107-113, 2018.

http://doi.org/10.1016/j.jssas.2016.01.008

Murphy J \& Riley JP. A single-solution method for the determination of soluble phosphate in sea water, Journal of the Marine Biological Association of the United Kingdom, 37 (1): 9-14, 1958. http://doi.org/10.1017/S0025315400014776

Murphy J \& Riley JP. A modified singles solution method for the determination of phosphate in natural waters, Analytica Chimica Acta, 27: 31-36, 1962.

http://doi.org/10.1016/S0003-2670(00)88444-5

Okalebo JR, Gathua KW \& Woomer PL, Laboratory Methods of Soil and Plant Analysis: A Working Manual, 2 Ed. ed., TSBF-CIAT and SACRED, Kenya 2002,

Oteino N, Lally RD, Kiwanuka S, Lloyd A, Ryan D, Germaine KJ \& Dowling DN. Plant growth promotion induced by phosphate solubilizing endophytic Pseudomonas isolates, Frontiers in Microbiology, 6: 745, 2015.

http://dx.doi.org/10.3389/fmicb.2015.00745

Parastesh F, Alikhani HA \& Etesami H. Vermicompost enriched with phosphate-solubilizing bacteria provides plant with enough phosphorus in a sequential cropping under calcareous soil conditions, Journal of Cleaner Production, 221: 27-37, 2019.

http://doi.org/10.1016/j.jclepro.2019.02.234

Paredes-Mendoza M \& Espinosa-Victoria D. Ácidos orgánicos producidos por rizobacterias que solubilizan fosfato: Una revisión crítica, Tierra Latinoamericana, 28 (1): 61-70, 2010. 
Patel K, Patel S, Parekh V \& Jha S. Isolation and characterization of salt tolerant phosphate solubilizing Serratia marcescens isolated from coastal area, Journal of Pure Applied Microbiology, 10 (3): 2401-2408, 2016.

Patiño Torres C \& Sánchez De Prager M. Aislamiento e identificación de bacterias solubilizadoras de fosfatos, habitantes de la rizósfera de chontaduro (b. gassipaes kunth) Biotecnología en el Sector Agropecuario y Agroindustrial, 10 (2): 177-187, 2012.

Paul NB \& Sundara Rao WVB. Phosphate-dissolving bacteria in the rhizosphere of some cultivated legumes, Plant Soil, 35 (1-3): 127-132, 1971. http://doi.org/10.1007/BF01372637

Petropoulos SA, Fernandes Â, Barros L, Ferreira ICFR \& Ntatsi G. Morphological, nutritional and chemical description of "Vatikiotiko", an onion local landrace from Greece, Food Chemistry, 182: 156-163, 2015.

http://doi.org/10.1016/j.foodchem.2015.03.002

Pramanik K, Kundu S, Banerjee S, Ghosh PK \& Mait TK. Computational-based structural, functional and phylogenetic analysis of Enterobacter phytases, 3 Biotech, 8: 262, 2018a. http://doi.org/10.1007/s13205-018-1287-y

Pramanik K, Pal P, Soren T, Mitra S, Ghosh PK, Sarkar A \& Maiti TK. In silico structural, functional and phylogenetic analysis of Klebsiella phytases, Journal of Plant Biochemistry and Biotechnology, 27: 362-372, $2018 \mathrm{~b}$.

http://doi.org/10.1007/s13562-018-0445-y

Preobrazhenskaya YV, Voskoboev AI \& Burd VN. Phosphatase activity of non-heme chloroperoxidase from the bacterium Serratia marcescens, FEBS Letters, 536 (1-3): 41-44, 2003. http://doi.org/10.1016/S0014-5793(03)00008-5

Rabin N, Zheng Y, Opoku-Temeng C, Du Y, Bonsu E \& Sintim HO. Biofilm formation mechanisms and targets for developing antibiofilm agents, Future Medicinal Chemistry, 7 (4): 493-512, 2015.

Rasul M, Yasmin S, Zubair M, Mahreen N, Yousaf S, Arif M, Sajid ZI \& Mirza MS. Phosphate solubilizers as antagonists for bacterial leaf blight with improved rice growth in phosphorus deficit soil, Biological Control, 136: 103997, 2019.

http://doi.org/10.1016/j.biocontrol.2019.05.016

Rodríguez Y, Cárdenas A \& Camelo C (2009) Protocolo para la determinacion de la actividad fosfatasa acida y alcalina en suelos - Laboratorio de Microbiologia Agrícola - Universidad Nacional de Colombia. pp: 5

Ruiz CF, Henao Gómez D, Lozano Borda M, Colorado LA, Mora Holguín H, Velandia Sánchez J, Navarro Morato O, Montes JO, Ariza Barbosa N, Cancino Salas R \& Salazar Acosta M (2012) Plan Estratégico Departamental de Ciencia, Tecnología e Innovación PEDCTI, Boyacá 2022. pp: 306.

Savardi M, Ferrari A \& Signoroni A. Automatic hemolysis identification on aligned dual-lighting images of cultured blood agar plates, Computer Methods and Programs in Biomedicine, 156: 13-14, 2018.

http://doi.org/10.1016/j.cmpb.2017.12.017 
Serna Posso EJ, Sánchez de Prager M \& Cisneros Rojas CA. Organic acids production by rhizosphere microorganisms isolated from a typic melanudands and its effects on the inorganic phosphates solubilization, Acta Agronómica 66 (2): 241-247, 2017.

http://doi.org/10.15446/acag.v66n2.56148

Sharma SB, Sayyed RZ, Trivedi MH \& Gobi TA. Phosphate solubilizing microbes: sustainable approach for managing phosphorus deficiency in agricultural soils, SpringerPlus, 2: 587, 2013.

Solankia M, Kundub BS \& Nehrac K. Molecular diversity of phosphate solubilizing bacteria isolated from the rhizosphere of chickpea, mustard and wheat, Annals of Agrarian Science, 16: 458-463, 2018. http://doi.org/10.1016/j.aasci.2018.05.007

Stella M \& Halimi MS. Gluconic acid production by bacteria to liberate phosphorus from insoluble phosphate complexes, Journal of Tropical Agriculture and Food Science, 43 (1): 41-53, 2015.

Suleman M, Yasmin S, Rasul M, Yahya M, Atta BM \& Mirza MS. Phosphate solubilizing bacteria with glucose dehydrogenase gene for phosphorus uptake and beneficial effects on wheat, Plos One, 13 (9): e0204408, 2018.

http://doi.org/10.1371/journal.pone.0204408

Swetha S \& Padmavathi T. Study of acid phosphatase in solubilization of inorganic phosphates by Piriformospora indica, Polish Journal of Microbiology, 65 (4): 407-412, 2016. http://doi.org/10.5604/17331331.1227666

Tabataba MA \& Bremner JM. Use of p-nitrophenyl phosphate for assay of soil phosphatase activity, Soil Biology and Biochemistry, 1 (4): 301-307, 1969.

Tahir M, Khalid U, Ijaz M, Shah GM, Naeem MA, Shahid M, Mahmood K, Ahmad N \& Kareem F. Combined application of bio-organic phosphate and phosphorus solubilizing bacteria (Bacillus strain MWT 14) improve the performance of bread wheat with low fertilizer input under an arid climate, Brazilian Journal of Microbiology, 495: 15-24, 2018.

http://doi.org/10.1016/j.bjm.2017.11.005

Tekeste N, Dechassa N, Woldetsadik K, Dessalegne L \& Takele A. Influence of nitrogen and phosphorus application on bulb yield and yield components of onion (Allium cepa L.), The Open Agriculture Journal, 12: 194-206, 2018.

http://doi.org/10.2174/1874331501812010194

Vaccari DA. Phosphorus: A Loomng, Scientific American: 54-59, 2009.

Valetti L, Iriarte L \& Fabra A. Growth promotion of rapeseed (Brassica napus) associated with the inoculation of phosphate solubilizing bacteria, Applied Soil Ecology, 132: 1-10, 2018. http://doi.org/10.1016/j.apsoil.2018.08.017

Vassilev N, Mendes G, Costa M \& Vassileva M. Biotechnological tools for enhancing microbial solubilization of insoluble inorganic phosphates, Geomicrobiology Journal, 31 (9): 751-763, 2014.

http://doi.org/10.1080/01490451.2013.822615

Wei Y, Zhao Y, Shi M, Cao Z, Lu Q, Yang T, Fan Y \& Wei Z. Effect of organic acids production and bacterial community on the possible mechanism of phosphorus solubilization during composting with enriched phosphate-solubilizing bacteria inoculation, Bioresource Technology, 247: 190-199, 2018. 
Yadav H, Fatima R, Sharma A \& Mathur S. Enhancement of applicability of rock phosphate in alkaline soils by organic compost, Applied Soil Ecology, 113: 80-85, 2017.

http://doi.org/10.1016/j.apsoil.2017.02.004

Yadav H, Gothwal RK, Mathur S \& Ghosh P. Bioactivation of Jhamarkotra rock phosphate by a thermotolerant phosphate-solubilizing bacterium Bacillus sp. BISR-HY63 isolated from phosphate mines, Archives of Agronomy and Soil Science 61 (81125-1135), 2015.

http://doi.org/10.1080/03650340.2014.980239

Yoldas F, Ceylan S, Mordogan N \& Esetlili BC. Effect of organic and inorganic fertilizers on yield and mineral content of onion (Allium cepa L.),, African Journal of Biotechnology, 10 (55): 11488-11492, 2011.

Zambrano-Moreno DC, Bonilla-Buitrago RR, Avellaneda L \& Zambrano G. Análisis prospectivo de los bioinsumos agrícolas en Colombia: una consulta a expertos, Revista Colombiana de Biotecnología 17 (2): 103-113, 2015a.

http://doi.org/10.15446/rev.colomb.biote.v17n2.48472

Zambrano-Moreno DC, Ramón-Rodríguez LF, Van Strahlen-Pérez M \& Bonilla-Buitrago RR. Industria de bioinsumos de uso agrícola en Colombia, Revista U.D.C.A Actualidad \& Divulgación Científica, 18 (1): 59-67, 2015 b.

Zendejas-Manzo GS, Avalos-Flores H \& Soto-Padilla MY. Microbiología general de Staphylococcus aureus: Generalidades, patogenicidad y métodos de identificación, Revista Biomédica, 25: 129-143, 2014.

Zhao Y, Hu M, Gao Z, Chen X \& Huang D. Biological mechanism of a novel hydro-electro hybrid priming recovers potential vigor of onion seeds, Environmental and Experimental Botany, 150: 260-271, 2018. http://doi.org/10.1016/j.envexpbot.2018.04.002

Zhu J, Li M \& Whelan M. Phosphorus activators contribute to legacy phosphorus availability in agricultural soils: A review, Science of the Total Environment, 612: 522-537, 2018. http://doi.org/10.1016/j.scitotenv.2017.08.095 
Producción de un bioinoculante compuestos por Pseudomonas sp., Serratia sp., y Kosakonia sp., efecto preliminar sobre el crecimiento de Allium cepa L. a escala de parcela

Resumen: El fósforo $(\mathrm{P})$ es un nutriente esencial para el desarrollo de las plantas, y su deficiencia restringe el rendimiento del cultivo. Para satisfacer los requerimientos de $\mathrm{P}$ en sistemas agrícolas, se diseñó un medio de cultivo de bajo costo (MT11B) en el cual se produjo un bioinoculante consistente en tres aislados de bacterias capaces de solubilizar P de roca fosfórica (PR). Pseudomonas sp., Serratia sp. y Kosakonia sp. exhibieron solubilización de $\mathrm{P}$ en agar SMRS1 modificado con PR $\left(5.0 \mathrm{~g} \mathrm{~L}^{-1}\right)$ como fuente de P inorgánico. Se hicieron siembras por aislamiento de las tres bacterias en agar-DNAsa y agar-sangre para descartar patogenicidad. En las pruebas de interacción no se observaron halos de inhibición; esto demostró que no hay antagonismo entre ellas, por lo cual fueron usadas para constituir un consorcio. La curva de crecimiento (12 h) en MT11B demostró crecimiento del consorcio en presencia de PR, hidrolizado de levadura de cerveza y glucosa a concentraciones $\left(2.5 \mathrm{~g} \mathrm{~L}^{-1}\right)$ cuatro veces menores que en SMRS1 $\left(10.0 \mathrm{~g} \mathrm{~L}^{-1}\right)$; se obtuvieron bacterias solubilizadoras de fosfato de $(10.60 \pm 0.08) \log _{10} \mathrm{CFU} \mathrm{mL} \mathrm{m}^{-1} \mathrm{y}$, a $6 \mathrm{~h}$ de cultivo, actividades volumétricas de las enzimas fosfatasa ácida y fosfatasa alcalina de (2.30 \pm 0.08$)$ UP y $(3.80 \pm 0.13)$ UP, respectivamente. El consorcio, que liberaba fósforo a una tasa de $(45.80 \pm 5.17) \mathrm{mg} \mathrm{L}^{-1}$ a $6 \mathrm{~h}$ de producción, se evaluó como bioinoculante en parcelas de cebolla durante cinco meses. Las plantas que recibían un tratamiento que incluía $500 \mathrm{~mL}\left(10 \times 10^{7} \mathrm{CFU} \mathrm{mL}^{-1}\right) \mathrm{de}$ bioinoculante $+100 \mathrm{~kg} \mathrm{ha}^{-1}$ de un fertilizante mineral orgánico exhibieron las variables de respuesta más altas $((170.1 \pm 22.2) \mathrm{mm}$ de altura del bulbo, $(49.4 \pm 6.5) \mathrm{mm}$ diámetro del diámetro del bulbo, $(9.0 \pm 1.8) \mathrm{g}$ peso seco del bulbo y $15.21 \mathrm{mg}$ de fósforo total por bulbo) $(p<0.05)$.

Palabras Clave: Bioinoculantes; roca fosfatada; Pseudomonas sp.; Serratia sp.; Kosakonia sp.; ácidos orgánicos; fosfatasas; Allium cepa $\mathrm{L}$. 
Produção de um bioinoculantes composto por Pseudomonas sp., Serratia sp., e Kosakonia sp., efeito preliminar na Allium cepa L., crescimento em escala de lote

Resumo: O fósforo (P) é um nutriente essencial para o crescimento das plantas e sua deficiência restringe o rendimento da colheita. Para atingir os requerimentos de $\mathrm{P}$ para uso na agricultura, os pesquisadores desenharam um meio de cultura de baixo custo (MT11B) composto por três isolados bacterianos capazes de solubilizar P a partir de rocha fosfática. Pseudomonas sp., Serratia sp. e Kosakonia sp. mostraram ação solubilizadora de $\mathrm{P}$ em ágar modificado com SMRS1 suplementado com PM $\left(5.0 \mathrm{~g} \mathrm{~L}^{-1}\right)$ como fonte de P inorgânico. Foram feitas culturas por isolamento das três cepas bacterianas em ágar DNAse e ágar sangue para descartar patogenicidade. Não foram observadas areolas de inibição nos testes de interação o que demonstrou que não havia antagonismo entre as espécies bacterianas. Consequentemente, as três espécies foram usadas para constituir um consórcio. Uma curva de crescimento (12 h) em MT11 demonstrou que o consórcio crescia na presença de PR, levedura de cerveja hidrolizada e glicose numa concentração de $\left(2.5 \mathrm{gL}^{-1}\right)$; quatro vezes menos do que aquelas em SMRS1 $\left(2.5 \mathrm{~g} \mathrm{~L}^{-1}\right)$. Obtiveram-se bacterias solubilizadoras de fosfato na quantidade de $(10.60 \pm 0.08) \log _{10} \mathrm{CFU} \mathrm{mL}^{-1}$ e, após $6 \mathrm{~h}$ de cultura, uma atividade volumétrica de enzimas fosfatases ácida e alcalina de $(2.3 \pm 0.8)$ UP e $(3.80 \pm 0.13)$ UP, respetivamente. Um consórcio que liberava $(45.80 \pm 0.17) \mathrm{mg} \mathrm{L}^{-1}$ após $6 \mathrm{~h}$ de produção foi avaliado como bioinoculante em lotes de cebola por cinco meses. As plantas que receberam um tratamento com $500 \mathrm{~mL}\left(10 \times 10^{7} \mathrm{CFU} \mathrm{mL}^{-1}\right)$ de bioinculante junto com $100 \mathrm{~kg} \mathrm{ha}^{-1}$ de fertilizante orgânico mineral mostraram as maiores variáveis de resposta determinadas: $(170.1 \pm 22.2) \mathrm{mm}$ de altura do bulbo, $(49.4 \pm 6.5) \mathrm{mm}$ de diâmetro de bulbo, $(9.0 \pm 1.8) \mathrm{g}$ de peso seco de bulbo e $15.21 \mathrm{mg} /$ bulbo de fósforo total $(p<0.05)$.

Palavras-chave: Bioinoculante; rocha fosfática; Pseudomonas sp; Serratia sp.; Kosakonia sp.; Ácidos orgânicos; Fosfatases; Allium cepa L. 


\section{Andrea Blanco-Vargas}

Currently, Ph.D. researcher in Biological Sciences from 2016 in the "Unidad de Investigaciones Agropecuarias" (UNIDIA), "Grupo de Biotecnología Ambiental e Industrial" (GBAI), and "Grupo de Agricultura Biológica" at "Pontificia Universidad Javeriana" (Bogotá, Colombia). Degree in Industrial Microbiology (2010) and M.Sc. in Biological Sciences (2013) from the same University. Her main interest focus is on environmental biotechnology, microorganisms of agricultural interest, native microorganisms with agro-industrial potential and agrosustainable production systems. She has also worked in bioremediation, sequential treatment biological/photocatalytic for the pollutants in wastewater.

ORCID: 0000-0002-1052-8226

\section{Lina M. Rodríguez-Gacha}

Microbiologist at FDA laboratories since 2021, degree Industrial Microbiology at "Pontificia Universidad Javeriana" (Bogotá, Colombia, 2019). In her degree, she developed her thesis in the Laboratory of Environmental Microbiology and soils and worked developing biological control in flowers at Cultivos Del Norte (Tocancipá, 2018) .Diploma degree in Integrated Quality Management Systems ISO 9001, 14001, 45001 at "Cámara de comercio Bogotá", 2019). Her main interests are validation of analytical methodologies used in the pharmaceutical industry, besides research and development of microbiological methodologies that can strengthen the quality systems present in the Colombian industry.

ORCID: 0000-0003-3305-2467

\section{Natalia Sánchez-Castro}

Industrial microbiologist from "Pontifica Universidad Javeriana" (Bogotá, Colombia 2019) she did her undergraduate thesis "Bioinoculant Production Composed of Pseudomonas sp., Serratia sp., and Kosakonia sp.: Effect of Phosphate Solubilizing Bacteria on Allium cepa L. growth at Plot Scale" in the Laboratory of Environmental Microbiology and Soils. She was part of the Environmental and Industrial Biotechnology Group (GBAI). She did her internship at Texas Tech University in Biology department in the research project Pharmaceuticals in Wastewater Effluent (Texas, 2018). Her research interests involve the microbial community role in degradation of pollutants and restorations of soils, her interest in research is manufacture of bioproducts and environmental protection.

ORCID: 0000-0002-7140-071X 


\section{Laura Herrera-Carlosama}

Industrial Microbiologist from the "Pontificia Universidad Javeriana" (March 2020), honorable mention to the thesis entitled "Evaluación de un fertilizante a base de bacterias fosfato solubilizadoras en presentación líquida y sólida sobre el crecimiento de Allium cepa L". Right hand helper in Micology. Research assistance at Pontificia Universidad Javeriana (Bogotá-Colombia, 2019), Industrial Microbiologist intern at Ingenio Providencia S.A (El Cerrito, Colombia, 2020). Microbiology Laboratory from the composting plant. Main interest related to organic fertilizers based on beneficial microorganism's research. Currently, Microbiologist Analyst at Gonher Farmacéutica LTDA from July 2020.

ORCID: 0000-0001-7605-5727

\section{Raúl A. Poutou-Piñales}

Currently, Professor at Microbiology Department from 1995, COLCIENCIAS Senior researcher from 2013 (Colombia). Technician in Analytical Chemistry at Chemistry Institute "Mártires de Girón" (1983); and Degree in Biochemistry at "Universidad de la Habana" (Ciudad de La Habana, Cuba, 1992). MSc in Microbiology (1999) and PhD in Biological Sciences at "Pontificia Universidad Javeriana" (Bogotá, D.C., Colombia, 2006). Leader of Environmental and Industrial Biotechnology Group (GBAI) from 1996. His main research interests are related to molecular biology and microbial biotechnology, focused on the expression of recombinant proteins and enzymes and their use in different industries such as food, pharmaceutical and agrobiological.

ORCID: 0000-0001-8841-2357

\section{Lucía A. Díaz-Ariza}

Microbiologist, Professor at Biology Department from 1999, COLCIENCIAS Associated researcher from 2013 (Colombia). Degree in Microbiology at "Universidad de los Andes" (1988). MSc in Biology (2001) at "Pontificia Universidad Javeriana". Her main research interests are related to soil microbiology, mycorrhizae in different agroecosystems, bioinoculant development and plant-microbe interaction.

She has directed the "Grupo de investigación en Agricultura Biológica" from 2011 and the Lab of Plant- microbe Interaction from 2001, heading projects and supervising undergraduate and graduate students. She is investigating the mycorrhizal fungi and the plant growth promoting microorganisms as crucial components of crop microbiota, where they act as biofertilisers.

ORCID: 0000-0001-5736-6335 


\section{Edna V. Gutiérrez-Romero}

Degree in Industrial Microbiology and M.Sc. in Biological Sciences at the "Pontificia Universidad Javeriana" (Bogotá D.C., Colombia). Director of research and development of the company Konservo SAS. Her main interest focus on Soil Microbiology, Agriculture and Precision Microbiology and Soil quality indicators.

ORCID: 0000-0002-7884-5252

\section{Claudia M. Rivera-Hoyos}

Researcher in the Environmental and Industrial Biotechnology Group (GBAI) at "Pontificia Universidad Javeriana" (Bogotá D.C., Colombia). Degree in Biology and M.Sc. in Biomedical Sciences at "Universidad del Quindío" (Armenia, Colombia). Ph.D. in Biological Sciences at "Pontificia Universidad Javeriana" (Bogotá D.C., Colombia). Her main interests focus on Molecular Biology, Bioinformatics, Biochemistry, cloning and expression of recombinant proteins and enzymes and their use in different industries such as food, pharmaceutical and agrobiological.

ORCID: 0000-0003-0915-8229

\section{Leidy D. Ardila-Leal}

Biologist at "Universidad de Pamplona" (Pamplona, Norte de Santander, Colombia, 2007). MSc in Biotechnology at "Universidad de Cordoba" (Montería, Córdoba, Colombia, 2012) and $\mathrm{PhD}$ in Biological Sciences at "Pontificia Universidad Javeriana" (Bogotá, D.C., Colombia). Her research and interest area is molecular biology, environmental biotechnology, structural bioinformatic and enzymes.

ORCID: 0000-0002-1346-5582

\section{Aura M. Pedroza-Rodríguez}

Currently, Professor at Microbiology Department from 2000, COLCIENCIAS Senior researcher from 2014 (Colombia). Bacteriology at "Pontificia Universidad Javeriana", (Bogotá, D.C., Colombia, 1995). MSc in Microbiology at "Pontificia Universidad Javeriana", (Bogotá, D.C., Colombia, 1999). PhD in Biological Sciences at "Centro de Investigaciones y de Estudios Avanzado CINVESTAV” (México, D.F., México, 2006). Her main research interests are related to waste and wastewater treatment using microorganisms and advanced oxidation processes. Coordinator of the Laboratory of Environmental Microbiology and Soils, Faculty of Sciences at Pontificia Universidad Javeriana (Bogotá, D.C., Colombia, 2006). 